\title{
Analysis of the agrotis segetum pheromone gland transcriptome in the light of Sex pheromone biosynthesis
}

Bao-Jian Ding ${ }^{*}$ and Christer Löfstedt

\begin{abstract}
Background: Moths rely heavily on pheromone communication for mate finding. The pheromone components of most moths are modified from the products of normal fatty acid metabolism by a set of tissue-specific enzymes. The turnip moth, Agrotis segetum uses a series of homologous fatty-alcohol acetate esters ((Z)-5-decenyl, (Z)-7-dodecenyl, and (Z)-9 tetradecenyl acetate) as its sex pheromone components. The ratio of the components differs between populations, making this species an interesting subject for studies of the enzymes involved in the biosynthetic pathway and their influence on sex pheromone variation.

Results: Illumina sequencing and comparative analysis of the transcriptomes of the pheromone gland and abdominal epidermal tissue, enabled us to identify genes coding for putative key enzymes involved in the pheromone biosynthetic pathway, such as fatty acid synthase, $\beta$-oxidation enzymes, fatty-acyl desaturases (FAD), fatty-acyl reductases (FAR), and acetyltransferases. We functionally assayed the previously identified $\triangle 11$-desaturase [GenBank: ES583599, JX679209] and FAR [GenBank: JX679210] and candidate acetyltransferases (34 genes) by heterologous expression in yeast. The functional assay confirmed that the $\Delta 11$-desaturase interacts with palmitate and produces (Z)-11-hexadecenoate, which is the common unsaturated precursor of three homologous pheromone component acetates produced by subsequent chain-shortening, reduction and acetylation. Much lower, but still visible, activity on $14 \mathrm{C}$ and $12 \mathrm{C}$ saturated acids may account for minor pheromone compounds previously observed in the pheromone gland. The FAR characterized can operate on various unsaturated fatty acids that are the immediate acyl precursors of the different $A$. segetum pheromone components. None of the putative acetyltransferases that we expressed heterologously did acetylate any of the fatty alcohols tested as substrates.

Conclusions: The massive sequencing technology generates enormous amounts of candidate genes potentially involved in pheromone biosynthesis but testing their function by heterologous expression or gene silencing is a bottleneck. We confirmed the function of a previously identified desaturase gene and a fatty-acyl reductase gene by heterologous expression, but the acetyltransferase postulated to be involved in pheromone biosynthesis remains illusive, in spite of 34 candidates being assayed. We also generated lists of gene candidates that may be useful for characterizing the acetyl-CoA carboxylase, fatty acid synthetase and $\beta$-oxidation enzymes.
\end{abstract}

Keywords: Agrotis segetum, Pheromone biosynthesis, Transcriptome, Desaturase, Fatty-acyl reductase, Acetyltransferase, Functional assay, Yeast expression

\footnotetext{
* Correspondence: bao-jian.ding@biol.lu.se

Pheromone Group, Department of Biology, Lund University, Sölvegatan 37,

SE-223 62 Lund, Sweden
}

(c) 2015 Ding and Löfstedt. Open Access This article is distributed under the terms of the Creative Commons Attribution 4.0 International License (http://creativecommons.org/licenses/by/4.0/), which permits unrestricted use, distribution, and reproduction in any medium, provided you give appropriate credit to the original author(s) and the source, provide a link to the Creative Commons license, and indicate if changes were made. The Creative Commons Public Domain Dedication waiver (http://creativecommons.org/publicdomain/zero/1.0/) applies to the data made available in this article, unless otherwise stated. 


\section{Background}

Moths rely heavily on sex pheromones for mate finding [1]. Usually the females produce and emit the pheromone from a specialized structure, the sex pheromone gland located at the intersegmental membrane between the $8^{\text {th }}$ and $9^{\text {th }}$ abdominal segment, associated with the ovipositor at the end of the adult female abdomen [2]. Over the last five decades, sex pheromones have been identified from more than 700 species $[3,4]$. The pheromone compounds are mostly fatty acid derivatives, with carbon chain length $\mathrm{C} 10-\mathrm{C} 18$, with $0-4$ double bonds [3], and an oxygenated functional group (alcohol, aldehyde, acetate ester) [3-5]. A substantial portion is made up by acetate esters [3]. Most moths use a combination of two or more compounds in a specific ratio, constituting a more or less species-specific blend. The pheromone biosynthesis pathways have been studied extensively and are well documented in many moth species [6, 7]. Characterization of the enzymes involved in the process of pheromone biosynthesis not only helps to understand the evolution of sexual communication and speciation, but could ultimately also aid in pest control by allowing the design of drugs that block the biosynthetic machinery or by allowing the synthetic biologist to produce species-specific pheromones for mass trapping or mating disruption in biological systems like cell factories or genetically modified plants [8-10].

During the last two decades, desaturases introducing double bonds into the acyl chain in $\Delta 6$ [11], $\Delta 9$ [12, 13], $\Delta 10$ [14], $\Delta 11$ [12, 13, 15-17] and $\Delta 14$ [18] position have been cloned from many moth species, and their functions have been characterized in various heterologous expression systems. Also an omega-desaturase that introduces a double bond in the methyl terminal carbon has been cloned and characterized [19]. In some cases, two double bonds can be produced by one desaturase [17] or by the consecutive activities of two desaturases [11]. These studies highlight desaturases as key players for the diversity of pheromone structures in moth species and their role in reproductive isolation and speciation. A variety of desaturases in combination with limited chain-shortening or chain-elongation account for the diversity of double bond isomerism observed among moth sex pheromone compounds.

After the double bonds are in place and the acyl chain length is adjusted, the carbonyl carbon is modified to form a functional group. Firstly it requires a step that converts the fatty-acyl precursors into fatty alcohols. Great progress has been made since the first fatty-acyl reductase gene was identified in Bombyx mori [20]. Several Ostrinia spp. FARs have been characterized [21, 22]. The Ostrinia FARs are very essential to determine the final pheromone compositions [22], minimal changes in sequence can cause the pheromone component ratio to shift dramatically [23]. On the other hand, there are also FARs that are very versatile in terms of substrate specificity $[24,25]$, involved in the biosynthesis of multicomponent pheromones.

Fatty alcohols serve as the actual pheromone components in a number of moth species [3], but mostly, fatty alcohols will be either oxidized to aldehydes [26-28] or esterified to form acetate esters [29-31]. Acetyltransferases are important enzymes since the acetate esters are very commonly occurring pheromone components among moth species. They have not been cloned from insects yet, but have been investigated in some cases by in vivo labeling studies [32-34]. Unlike FARs, these functional group modification enzymes have not been studied extensively.

The chain-shortening pathway has not been characterized at the enzymatic level in insects, but it was noted in a couple of cases that mutations in the $\beta$-oxidation pathway did affect the final pheromone compositions. The major pheromone component of cabbage looper moth Trichoplusia $n i$ is Z7-12:OAc, whereas a mutant strain produced a greatly increased amount of Z9-14:OAc [35, 36].

The turnip moth, $A$. segetum uses a series of short chain acetate esters as sex pheromone components, including the homologues ( $Z$ )-5-decenyl, ( $Z$ )-7-dodecenyl, and $(Z)-9$ tetradecenyl acetate (Z5-10:OAc, Z7-12:OAc, and Z9-14:OAc) [37-39]. The biosynthesis of this type of pheromone involves desaturation of palmitic acid (16C), a product of the ubiquitous fatty acid synthase machinery. The unsaturated fatty acid undergoes chain shortening, reduction, and acetylation [38]. Populations of $A$. segetum from different geographic areas differ in the ratio of their pheromone components [40, 41]. For instance the Swedish population has a ratio of Z914:OAc/Z7-12:OAc/Z5-10:OAc $=29 / 59 / 12$ whereas the Zimbabwean population has a ratio of $2 / 20 / 78$ [37]. This shift in ratios could be due to differences in the chainshortening, in the FAR activity or less likely in the activity of the acetyltransferase.

An EST-library was previously constructed from the $A$. segetum pheromone gland, revealing candidate genes involved in pheromone production [42] and a $\Delta 11$ desaturase and a FAR involved in pheromone production were already characterized [9]. The EST library, however, contains only 2, 285 objects. We now report a more extensive database of candidate genes potentially involved in the A. segetum sex pheromone biosynthetic pathway, generated by next generation sequencing technology (NGS). We constructed transcriptome libraries from two tissues of A. segetum: pheromone gland (As_PG) and abdomen (As_AB). Furthermore, to test the function of several of the candidate genes we assayed them in a yeast heterologous expression system. 


\section{Results and discussion}

Illumina sequencing, unigene assembly, and analysis of transcripts

In total 53 million raw clean reads were obtained from each (As_PG and As_AB) library, with a total of 4.8G clean nucleotides in each (Table 1). The clean reads from the two libraries were assembled into 62,165 consensus contigs (Table 2), including 22,633 distinct clusters (referred to as CL) and 39,532 distinct singletons (referred to as Unigene). These consensus contigs have a mean length of $733 \mathrm{nt}$, and N50 [43] =1,150, total length $45 \mathrm{Mb}$. Size distributions of the unigenes can be seen in Fig. 1 and their differential expression in the two tissues is displayed in Fig. 2. This transcriptome shotgun assembly project has been deposited at DDBJ/EMBL/GenBank under the accession GBCW00000000. The version described in this paper is the first version, GBCW01000000.

After alignment by blastx to protein databases NCBI Nr, Swiss-Prot, KEGG and COG (e-value $<0.00001$ ), and alignment by blastn to nucleotide database NCBI Nt, annotations were retrieved from the highest sequence similarity with the given unigenes along with their protein functional annotations. About half of the unigenes have a hit in one or more of the databases (Table 3). 14,108 unigenes hit the first record in the $\mathrm{Nr}$ database with Bombyx mori (Table 4). A. ipsilon got 293 hits, but this does not mean the $A$. segetum is closer to $B$. mori than $A$. ipsilon, it is just because the $B$. mori got more records deposited in GenBank than A. ipsilon. In terms of clusters of orthologous groups (COG), 19,911 unigenes were classed in one or more of the 26 COG functional categories (Fig. 3).

By running the Blast2GO program [44] using $\mathrm{Nr}$ annotation, 11,246 (18\%) unigenes were assigned to one or more GO categories. The GO terms cellular process, binding, catalytic activity, and metabolic process were the most abundantly represented categories (over 5,000 unigenes, details see Fig. 4). These numbers and percentages are similar to the results that $\mathrm{Gu}$ and coauthors [45] presented from A. ipsilon.

The biosynthetic pathway (Fig. 5) leading to the pheromone components of $A$. segetum is similar to what has been reported for many other moth species [37, 45]. The key players among enzymes involved or postulated to be involved are desaturases, $\beta$-oxidation enzymes, fatty-acyl reductases, and acetyltransferases. Pheromone biosynthesis is reported to be under control by a pheromone biosynthesis activating neuropeptide (PBAN) [46]. In the following we present candidate genes related to each step in the biosynthetic pathway, their expression levels and their functional assay in yeast heterologous expression systems.

\section{Pheromone biosynthesis activating neuropeptide (PBAN) receptor}

PBAN is released from the subesophageal ganglion (located near the brain) and is transported through hemolymph (or via the ventral nerve cord) to the pheromone gland. Upon binding to the PBAN receptor present on the pheromone gland cell membrane [47], it will induce the opening of calcium channels causing influx of extracellular calcium [7]. Then the calcium binds to calmodulin, that stimulates phosphatase (and/or kinase), which subsequently activates the FAR in the case of Bombyx mori [48] or in other cases the acetyl-CoA carboxylase [49] or the acetyltransferase [50] maybe regulated. In As_PG, we found one gene, Ase_17579 [GenBank: KJ622075], which is $97 \%$ identical to Helicoverpa zea PBAN receptor. Its expression level is similar in As_PG and As_AB, 15.6 FPKM and 16.9 FPKM, respectively.

\section{Acetyl-CoA carboxylase}

The rate-limiting step in fatty acid biosynthesis [51] is the ATP-dependent carboxylation of acetyl-CoA to malonylCoA catalyzed by acetyl-CoA carboxylase (ACCase) [52], the first step in saturated long chain fatty acid biosynthesis. ACCase is a large protein with multiple catalytic activities, working coordinately and providing malonylCoA substrate for the biosynthesis of fatty acids [50]. In $A$. segetum, we found one contig Ase_7442 (KJ622074), encoding the full-length of this protein. It shares $69 \%$ amino acid identity with the ACCase of Tribolium castaneum and $88 \%$ aa identity with $B$. mori ACCase. The expression level of Ase_7442 is not significantly different in As_AB (37 FPKM) and in As_PG (26 FPKM).

\section{Fatty acid synthase}

Fatty acid synthase (FAS) is a multifunctional protein [52] that produces saturated fatty acids using malonyl$\mathrm{CoA}$ and acetyl-CoA as substrate and that requires $\mathrm{NADPH}$ as reducing agent, in a cyclic process in which an acetyl primer undergoes a series of decarboxylative condensations with several malonyl moieties [53]. The resulting products are palmitic and stearic acid in insects,

Table 1 Output statistics of sequencing

\begin{tabular}{|c|c|c|c|c|c|c|}
\hline Sample & Total raw reads & Total clean reads & Total clean nucleotides & Q20 \% & $N \%$ & GC \% \\
\hline$\overline{A s \_P G}$ & $63,086,832$ & $53,235,252$ & $4,791,172,680$ & $96.61 \%$ & $0.01 \%$ & $47.54 \%$ \\
\hline As $A B$ & $62,193,108$ & $54,156,050$ & $4,874,044,500$ & $96.62 \%$ & $0.01 \%$ & $47.44 \%$ \\
\hline
\end{tabular}

Q20 percentage is proportion of nucleotides with quality value larger than 20 in reads (sequencing error rate $=1 \%$ ); $\mathrm{N}$ percentage is proportion of unknown nucleotides in clean reads. GC percentage is proportion of guanidine and cytosine nucleotides among total nucleotides 
Table 2 Statistics of assembly quality

\begin{tabular}{lllllll}
\hline Sample & Total length $(\mathrm{nt})$ & Mean length $(\mathrm{nt})$ & N50 & Total consensus sequences & Distinct contigs & Distinct singletons \\
\hline As_PG & $37,824,354$ & 574 & 907 & 65,840 & 17,534 & 48,306 \\
As_AB & $36,392,640$ & 618 & 1007 & 58,847 & 13,055 & 45,792 \\
All & $45,545,001$ & 733 & 1150 & 62,165 & 22,633 & 39,532 \\
\hline
\end{tabular}

$\mathrm{N} 50$ value defined as the length for which the collection of all sequences of that length or longer contains at least half of the sum of the lengths of all sequences

as proven by labeling studies $[49,53,54]$. We found six unigenes (KJ622068-KJ622073) that are homologous to the Aip_FAS_JX989151 [45]. In total, these unigenes are seven times more expressed (significant) in As_PG than in As_AB (FPKM 67.1 / FPKM 9).

\section{Desaturases}

Fatty acid desaturases catalyze the introduction of double bonds into acyl chains with strict regioselectivity and stereoselectivity, and can be divided into four categories [55]: 1) first desaturases, inserting a double bond into the saturated acyl chain; 2) frontend desaturases, introducing a double bond between an existing double bond and the carboxylic end; 3) omega desaturases, inserting a double bond between an existing double bond and the methyl end; 4) sphingolipid desaturases, introducing double bonds into sphingolipids which are important components of eukaryotic plasma membranes. We found 10 desaturase candidates from the two tissues, and they belong to the first desaturase $(7 / 10)$, the front-end desaturase

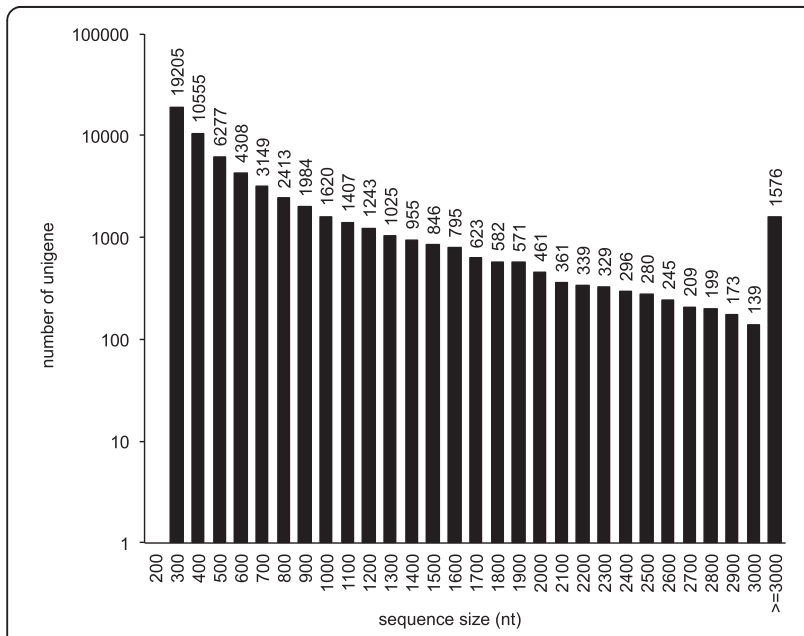

Fig. 1 Length distribution of unigenes. The consensus sequence lengths ranging from $200 \mathrm{bp}$ to more than 3,000 bp, and above each column is indicated the number of genes of each length range. The most abundant unigenes are $300 \mathrm{bp}$ (19205) and the least abundant unigenes were 3000 bp (139); sequences over 3000 bp were grouped together. The number of sequences decreased as the length increased
$(2 / 10)$, and the sphingolipid desaturase (1/10) subfamilies. Among the first desaturase subfamily, several groups have been recognized based on phylogenetic and functional analysis and a four-letter "signature motif" has been suggested for each of them as shown in Fig. 6. These signature motifs strongly associate with the location of double bond that the desaturase is inserting in the fatty-acyl chain, with less emphasis on the chain length selectivity: $\Delta 9$ _KPSE $(\mathrm{C} 16>\mathrm{C} 18)$ desaturases and $\Delta 9$ _NPVE $(\mathrm{C} 18>\mathrm{C} 16)$ desaturases that are mostly involved in fatty acid metabolism [56], and $\Delta 11, \Delta 10$ and bifunctional desaturases with the "xxxQ" motif (with a few exceptions having "xxxE" motif) exclusively involved in pheromone biosynthesis [13, 57] (Fig. 6). The Ase_1623 and Ase_4567 have the signature motif of KPSE and NPVE, respectively, that strongly suggest their roles in ordinary metabolic pathways as $\Delta 9$ desaturases. The Ase_21308 and Ase_5534 both have "xxxQ" motif, suggesting that they represent $\Delta 11$ desaturases. The Ase_5534 is the obvious candidate for pheromone biosynthesis since

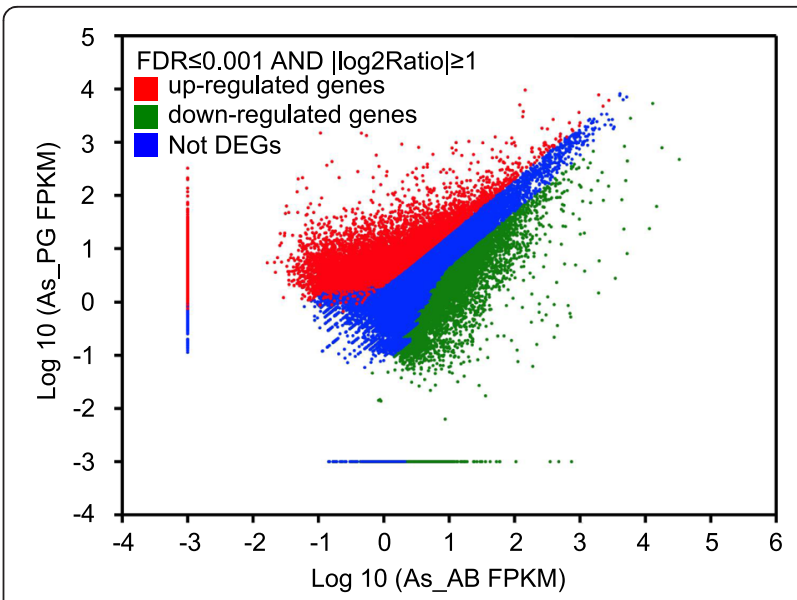

Fig. 2 Differentially expressed unigenes displayed by FPKM in As_PG versus $A s \_A B$, in $\log _{10}$ scale. $X$-axis (As_AB) and $Y$-axis (As_PG) shows the logarithm value of normalized expression of each gene in FPKM (Fragments per kb per Million fragments). There are 21,965 unigenes that are up regulated (red dots), measured by As_PG(FPKM)/As_AB(FPKM) $>2$. On the contrary, 14,292 unigenes are down regulated (green dots), since their As_PG(FPKM)/As_AB(FPKM) $<0.5$. Most of the unigenes, 25,895, were equally expressed (blue dots) in both tissue $(0.5<$ As_PG(FPKM)/As_AB(FPKM) $<2)$ 
Table 3 Summary of annotation results

\begin{tabular}{llllll}
\hline $\mathrm{Nr}$ & $\mathrm{Nt}$ & SwissProt & KEGG & COG & GO \\
\hline 27,344 & 20,403 & 19,143 & 17,351 & 8,502 & 12,049 \\
\hline
\end{tabular}

Unigenes were annotated with the databases of $\mathrm{Nr}$, Nt, Swiss-Prot, KEGG, COG and GO. Then counted the number of unigenes annotated with each database. The result is summarized as the follow table

its expression level in As_PG is 1-2 magnitudes higher than any other candidate, and it has a very low expression level in As_AB. The functional assay confirms that it possess the ability of creating a $\Delta 11$ double bond mainly on palmitate (Fig. 7), corroborating that Ase_5534 [GenBank:KJ622051] is the desaturase responsible for pheromone production in A. segetum. This result is consistent with the recent study in which this gene was expressed in different yeast strains [9] and this desaturase was as a matter of fact found already in the EST analysis reported by Strandh et al. [42]. This desaturase introduces a double bond with $\mathrm{Z}$ configuration on 16:Acyl. Besides Z11-16:Acyl, some other minor products were detected: $\Delta 11-12: A c y l, Z 11-14: A c y l$, E11-14:Acyl, and Z11-15:Acyl (Fig. 7). The Ase_21308 displayed no activity in our yeast expression system. Gu et al. [45] found a desaturase that is very close to our Ase_5534 (as shown in Fig. 6) and which should be the one involved in pheromone biosynthesis in A. ipsilon. Compared to [42, 45, 58], our dataset includes a larger set of desaturases isolated from the moth pheromone gland and surrounding tissues.

\section{$\beta$-oxidation enzymes}

After the palmitate has undergone $\Delta 11$ desaturation in the A. segetum pheromone gland, it is subject to limited chain shortening by $\beta$-oxidation, resulting in three homologous fatty-acyl pheromone precursors with 14C, 12C, and $10 \mathrm{C}$ chain length (Fig. 5). Chain-shortening by $\beta$ oxidation is the action of a series of enzymes, working sequentially and forming a reaction spiral.

In the first reaction, acyl-CoA is converted to E2enoyl-CoA, by acyl-CoA oxidases (in peroxisomes) and

Table $4 \mathrm{Nr}$ annotations of assembled $\mathrm{A}$. segetum consensus sequences

\begin{tabular}{lll}
\hline Species & Gene numbers & Percentage \\
\hline Bombyx mori & 14,108 & $50.56 \%$ \\
Danaus plexippus & 7,807 & $27.98 \%$ \\
Tribolium castaneum & 642 & $2.3 \%$ \\
Papilio xuthus & 569 & $2.04 \%$ \\
Helicoverpa armigera & 420 & $1.51 \%$ \\
Agrotis ipsilon & 293 & $1.05 \%$ \\
Other & 4063 & $14.56 \%$
\end{tabular}

The first column shows the species with the highest number of similar genes in descending order, the second column indicates the number of these annotated genes, and the last column shows the percentage of genes with respect to the total annotated genes sequences
acyl-CoA dehydrogenases (in mitochondria). Four acylCoA dehydrogenases with different chain length specificities cooperate to assure that the complete degradation of all fatty acids with different chain length. The names of the four dehydrogenases, short-chain, medium-chain, long-chain, and very long-chain acyl-CoA dehydrogenases, reflect their chain-length specificities. Short-chain acyl-CoA dehydrogenase only acts on short-chain substrates like butyryl-CoA and hexanoyl-CoA. Mediumchain acyl-CoA dehydrogenase is most active with substrates from hexanoyl-CoA to dodecanoyl-CoA, whereas long-chain acyl-CoA dehydrogenase preferentially acts on octanoyl-CoA and longer-chain substrates [59]. Verylong-chain acyl-CoA dehydrogenase extends the activity spectrum to longer-chain substrates, including those having acyl chains of 22 and 24 carbon atoms [60]. We found a full spectrum of dehydrogenases and oxidases in A. segetum (Table 5). It is noteworthy that unigene6715 was expressed 72 times higher (386FPKM) in As_PG than in As_AB (5FPKM). In addition, we found two unigenes of isovaleryl-CoA dehydrogenase, which is specific for metabolism of branched-chain fatty acids [61].

The second step of $\beta$-oxidation E2-enoyl-CoA is reversibly hydrated by enoyl-CoA hydratase to L-3hydroxyacyl-CoA. Two categories of enoyl-CoA hydratases have been identified in mitochondria [62]. One is specialized for crotonyl-CoA (4C). The second one is long-chain enoyl-CoA hydratase, effectively hydrates medium-chain and long-chain substrates. Long-chain enoyl-CoA hydratase is a component enzyme of the trifunctional $\beta$-oxidation complex, which additionally exhibits long-chain activities of L-3-hydroxyacyl-CoA dehydrogenase and 3-ketoacyl-CoA thiolase [63], and resides in the inner mitochondrial membrane. We found six enoyl-CoA hydratases from $A$. segetum (Table 5), with similar expression level in both As_PG and As_AB.

The third reaction is the reversible dehydrogenation of L-3-hydroxyacyl-CoA to 3-ketoacyl-CoA catalyzed by $\mathbf{L}$-3hydroxyacyl-CoA dehydrogenase. Four categories of L-3hydroxyacyl-CoA dehydrogenases have been identified in mitochondria. Long chain L-3-hydroxyacyl-CoA dehydrogenase is a component enzyme of the trifunctional $\beta$-oxidation [63], which is most active with long-chain substrates. Medium-chain and short-chain L-3-hydroxyacyl-CoA dehydrogenase, are both soluble matrix enzymes, processing medium- and short-chain substrates. These three enzymes complement each other and thus assure high rates of dehydrogenation over the whole spectrum of $\beta$-oxidation intermediates [63]. In $A$. segetum this group of enzymes is represented by five unigenes (Table 5 ), with similar expression level in both tissues.

The final step in which 3-ketoacyl-CoA is cleaved by thiolase between its $\alpha$ and $\beta$ carbon atoms, makes the 


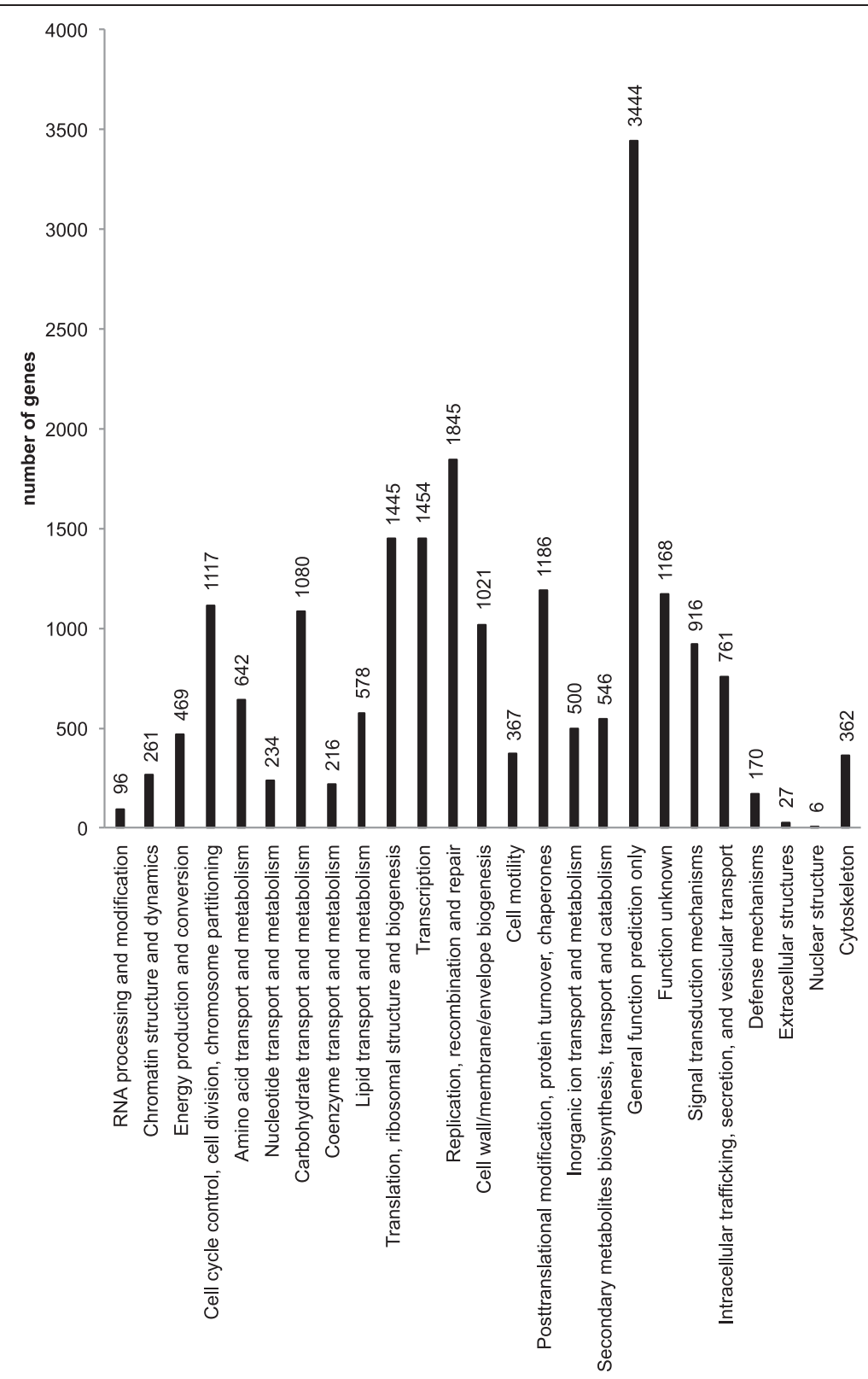

Fig. 3 COG classification of unigenes. Histogram of COG classifications of assembled consensus sequences. Results are presented for the 25 main COG categories. The number above the column indicates number of unigenes in each category

substrate two carbons shorter. Three classes of thiolase exist in motochondria: acetoacetyl-CoA thiolase or acetylCoA acetyltransferase (specific for acetoacetyl-CoA), 3ketoacyl-CoA thiolase or acetyl-CoA acyltransferase (act on C4-C16), and long-chain 3-ketoacyl-CoA thiolase that is a component enzyme of the membrane-bond trifunctional $\beta$ oxidation complex, whereas the first two thiolases are soluble matrix enzymes [62]. We found six unigenes of 3ketoacyl-CoA thiolase from A. segetum (Table 5), and all of them expressed at similar level in As_PG and As_AB.

The degradation of unsaturated fatty acids requires auxiliary enzymes like $\Delta 3, \Delta 2$-enoyl-CoA isomerase and
2,4-dienoyl-CoA reductase to modify the structure of double bonds during the $\beta$-oxidation process to ensure a continuous flow of intermediates through the $\beta$-oxidation spiral [64]. We found two unigenes of the $\Delta 3, \Delta 2$-enoylCoA isomerase, one mitochondrial type and one peroxisomal. In addition, we found a $\Delta 3,5 \Delta 2,4$-dienoyl-CoA isomerase that is specialized for processing odd-numbered double bonds [61].

Insects in general have the ability to shorten longchain fatty acids to a specific shorter chain length [65]. Jurenka $[5,66]$ suggests that this kind of limited chain shortening takes place in the peroxisomes. Unlike the $\beta$ - 


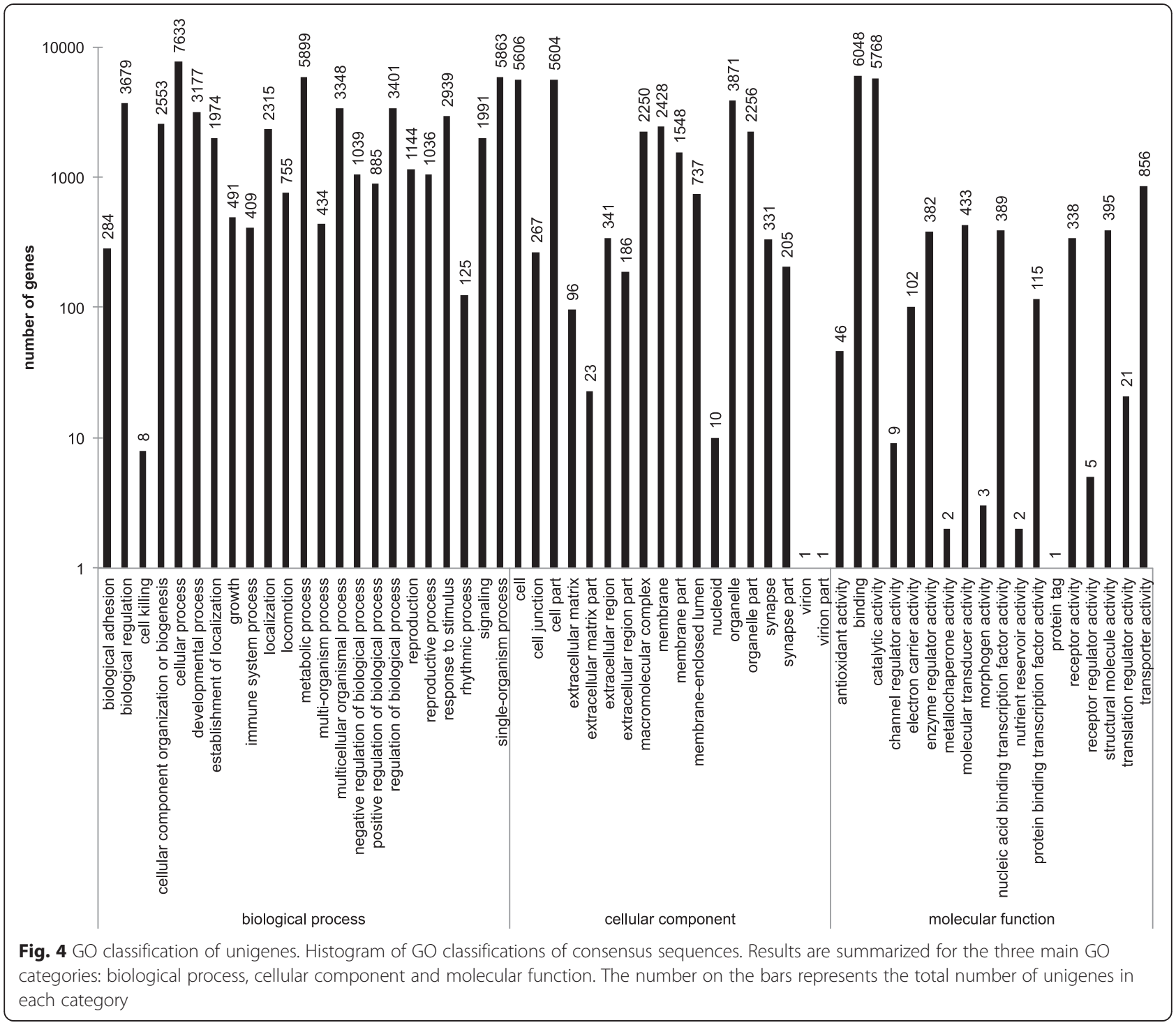

oxidation in mitochondria in which substrates are thoroughly degraded into two-carbon units, the $\beta$-oxidation in peroxisomes ceases at the formation of medium-chain fatty-acyl-CoAs, because acyl-CoA oxidase is inactive toward substrates having acyl moieties of eight or fewer carbon atoms [66]. Moth pheromone components are commonly $12 \mathrm{C}$ and $14 \mathrm{C}$, suggesting that there is still something specific about the chain-shortening being involved in moth pheromone biosynthesis.

In the present study we found representatives of all the key players and auxiliary enzymes of $\beta$-oxidation, and some of them are very high in expression level and differentially expressed among the As_PG and As_AB (Table 5), forming promising candidates to tackle the role of $\beta$-oxidation on pheromone biosynthesis either by heterologous expression or by RNAi.

\section{Fatty-acyl reductases}

Chain-shortened fatty-acyl precursors are reduced to the corresponding alcohols by Fatty-Acyl Reductases (FARs) [20]. FARs have been cloned and characterized from several moth species [21-23] since the first one was found in B. mori [20]. We found ten full-length unigenes in both the As_PG and As_AB (Fig. 8) and two of them cluster within the $p g F A R$ clade [25]. We expressed the two ORFs that belong to the pheromone-producing clade in our yeast expression system. The results showed that it is the one named Ase_1929 that is responsible for reducing all the three fatty-acyl precursors (Z5-10:CoA, Z7-12:CoA, Z9-14:CoA) into their corresponding fatty alcohols (Fig. 9), and it is the most abundant transcript among all these ten unigenes (Fig. 8). This result is consistent with previous findings that a single FAR takes a 


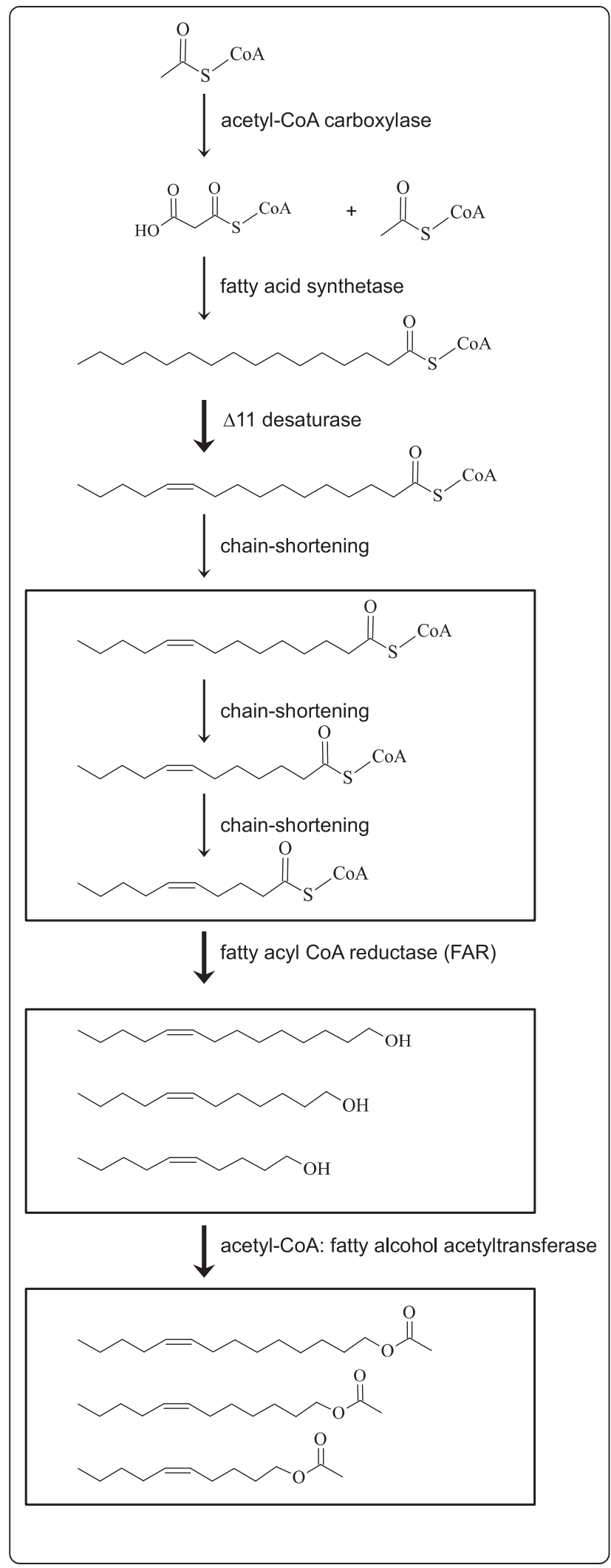

Fig. 5 Biosynthetic pathway leading to the sex pheromone of Agrotis segetum, modified from [37]. It starts with carboxylation of acetyl-CoA to malonyl-CoA, and then they are entered to a cycle of fatty acid synthesis and end up with common fatty acids stearate and palmitate. The $\Delta 11$ desaturase inserts a double bond in the acyl chain and then the unsaturated fatty acid is subjected to three rounds of chain-shortening by $\beta$-oxidation, forming three acyl-chains different by two carbon atoms. These acyl-chains are then reduced by fatty-acyl CoA reductase (FAR) to make fatty alcohols, which are then acetylated to acetate esters, the final A. segetum pheromones. Thick arrows represent steps are functionally assayed in heterologous systems

wide range of the fatty-acyl substrates and convert them into fatty alcohols [24, 25, 67]. Our results complement the findings of Hagström et al. [9], who presented the Ase_1929 with longer chain acyl substrates (16C) and found it to be very active on them. But what appears in Fig. 9 as if the Ase_1929 when expressed in yeast is more active towards longer chain length substrates than towards shorter ones, does not necessarily represent its actual activity in the pheromone gland. This difference could partly be due to the volatility of the substrates and products, since shorter chain methyl esters and alcohols are more volatile and thus may escape from the yeast expression system during incubation. The other unigene Ase_20982 which also clustered with the $p g F A R$ clade, did not show any function in our heterologous expression system. The FAR [GenBank: JX989146, protein ID: AGR49323] found by Gu et al. [45] clustered very close to our Ase_1929, suggesting that it is likely involved in pheromone biosynthesis in A. ipsilon.

\section{Acetyltransferases}

The genes involved in acetylation of fatty pheromone alcohols have not been cloned from any insect species. Acetyltransferases probably belong to a huge family of acyl CoA-utilizing enzymes whose products include a variety of chemicals, such as neurotransmitters [68], plant volatile esters [69, 70], constitutive defense compounds, waxes [71], phytoalexins, lignin, phenolics, alkaloids, and anthocyanins [72-74], which makes it very difficult to make functional predictions from primary sequence information alone. Attempts have been made but ended up with getting other member of the family [75]. This step is the last step in the A. segetum pheromone biosynthetic pathway. Most likely it does not significantly influence the ratio between the homologous acetate pheromone components [32, 33], although in several moth species the $\mathrm{Z}$ isomers are produced faster than the $E$ isomers and yield more products, when the alcohol substrates were supplied to the pheromone gland homogenate [34]. Previously, a number of acetyltransferases that were cloned from plant species were studied. For example, the kiwi alcohol acetyltransferase AT9 


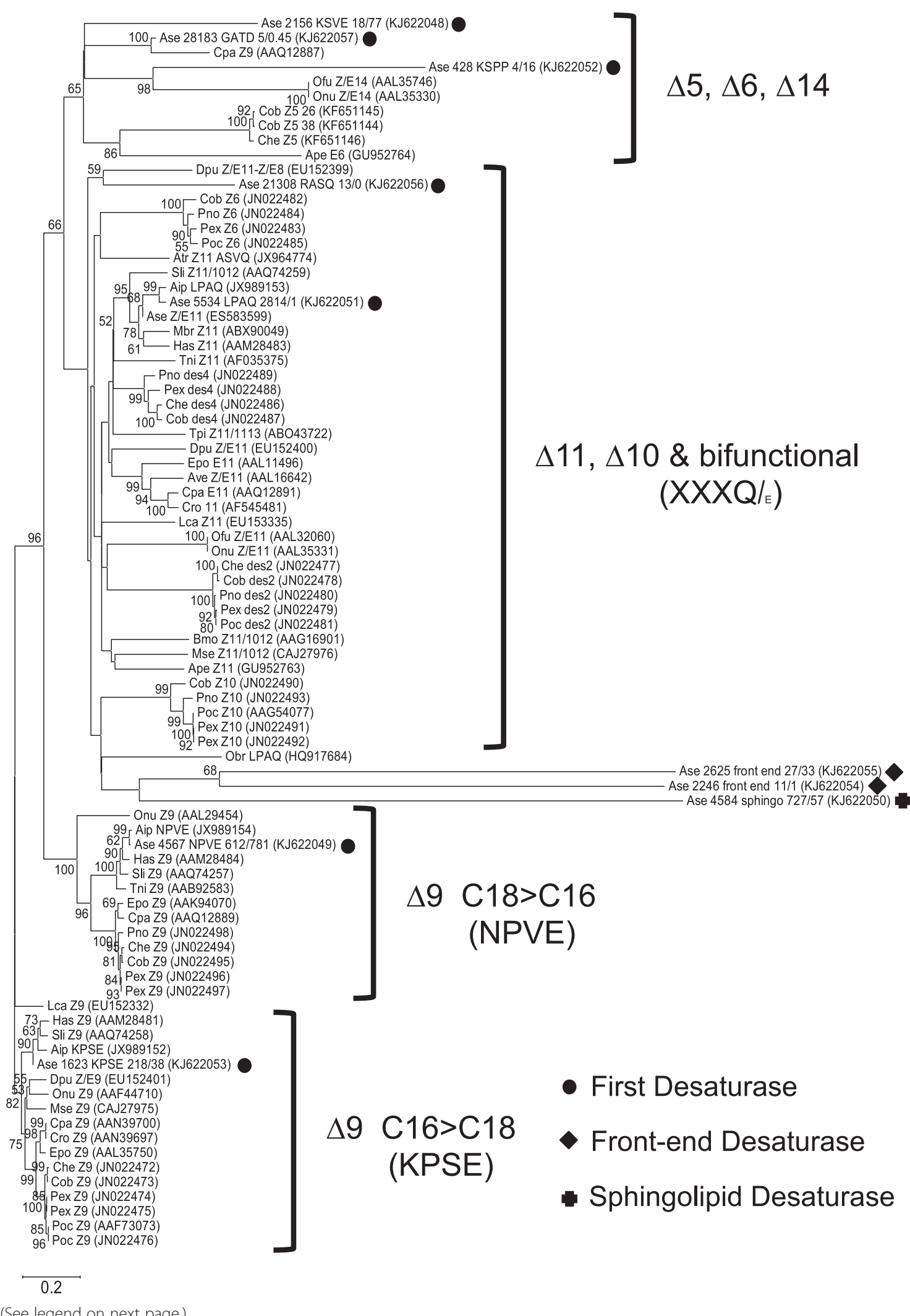

Fig. 6 (See legend on next page.) 
(See figure on previous page.)

Fig. 6 The neighbor-joining tree of selected lepidopteran desaturase genes, constructed using amino-acid sequences. Desaturases described in this study are indicated by different shapes (with signature motif displayed for the First Desaturase), followed by unigene expression levels in the gland and abdomen library, respectively (As_PG_FPKM /As_AB_FPKM). Desaturases in previous studies are named as follows: biochemical activities (if known) are indicated in connection to the species name, followed by accession number in parenthesis. Most of the desaturases used in here are First Desaturases that introduce double bond into saturated fatty acids. Among the First Desaturase, four distinctive groups formed that separate their biological functions. The $\Delta 9$ desaturases are usually used for normal fatty acid metabolism, with the "KPSE" group having preference on C16 and "NPVE" group mainly modifying C18. The $\triangle 11, \Delta 10$ and bifunctional desaturases with the "XXXQ" motif (with a few exceptions having "XxxE" motif) exclusively involved in pheromone biosynthesis. The $\Delta 5, \Delta 6, \Delta 14$ group contain a mixture of different signature motifs derived from the $\Delta 9$ and $\Delta 11$ groups, and their biological function are also diverged. The tree was rooted on the $\Delta 9$-desaturase-KPSE (C16 > C18) functional class

produced butyl acetate and butyl propionate with highest catalytic activities when tested with short chain alcohols [69]. Another example is the apple alcohol acyltransferases (MpAAT1) that use coenzyme A (CoA) donors together with alcohol acceptors as substrates, which were cloned and characterized [76]. The MpAAT1 recombinant enzyme can utilize a range of alcohol substrates from short to medium straight chain (C3-C10), branched chain, aromatic and terpene alcohols. The enzyme can also utilize a range of short to medium chain CoAs [76], but alcohols longer than $\mathrm{C} 10$ have not been tested. Similar work was done with enzymes forming volatiles esters from banana, melon, and strawberry. The recombinant enzymes were capable of producing esters from a wide range of alcohols and acylCoA $[70,77,78]$. Overall, these enzymes are members of the BAHD $[73,74]$, generally recognized by their active site motif (HXXXD) and a conserved region (DFGWG) with likely structural significance [69]. A tBLASTn search with current published BAHDs as query against our A. segetum transcriptome got no hit, suggesting this moth may not express this gene family in its pheromone gland or they have undergone substantial evolutionary changes. But according to previously published putative acetyltransferase $[45,58]$ and the annotation results we found 34 candidates in our transcriptome (Table 6) and we heterologously expressed them in our yeast system. The ORF of each of these putative acetyltransferases was thus cloned into a yeast expression vector, pYES-DEST52, under the control of galactose inducible promoter. The $\triangle A T F 1$ yeast strain (knock out strain that lacking most of the acetylation activity) was transformed with an individual construct and incubated in liquid culture with the culture medium supplemented with a mixture of Z9-14:OH, Z7-12:OH and Z5-10:OH. After incubation for 2 days, the total lipids were extracted and analyzed by GC-MS for acetate esters. The results did not reveal any of insect candidate genes being capable of esterifying fatty alcohols into acetate esters (Fig. 10), whereas the strain overexpressing ATF1 was highly active (positive control).

\section{Conclusions}

We explored the data obtained from massive sequencing of pheromone producing tissue of the turnip moth and compared the expression levels of candidate unigenes with their expression levels in the abdominal epidermal tissue. This allowed identification of key parts involved in the pheromone biosynthesis pathway such as: $\beta$ oxidation enzymes, a desaturase, a fatty-acyl reductase, putative acetyltransferases, and other components involved in the fatty-acid metabolism, like acetyl-CoA carboxylase and fatty-acid synthetase. By phylogenetic analyses of desaturases and FARs, we found the most promising candidates for each gene and confirmed their function in pheromone biosynthesis. The $\Delta 11$-desaturase is a specialist interacting preferentially with $16: \mathrm{CoA}$ and producing Z11-16:CoA. The FAR we found is a generalist that can reduce a broad range of saturated and unsaturated acyl substrates from $10 \mathrm{C}$ to $16 \mathrm{C}$. We had specifically hoped to be able to clone and characterize an acetyltransferase involved in pheromone biosynthesis that has been postulated in many studies. We tested 34 genes that were annotated to be acetyltransferases in our yeast expression system (which can successfully express plant-derived acetyltransferase [10]) but it turned out that none of them was functional in comparison to the ATF1 positive control. The nature of the acetyltransferase involved in moth pheromone biosynthesis remains illusive. In addition, we generated a list of $\beta$-oxidation enzymes, ACC and FAS that can be further tested either by heterologous expression or by RNAi.

\section{Methods}

\section{Insects and tissue collection}

Agrotis segetum were obtained from a laboratory culture, continuously maintained for more than 20 years in Lund, but repeatedly rejuvenated by addition of field-collected insects. The larvae were reared on a semisynthetic beanbased diet [79] and kept at $25{ }^{\circ} \mathrm{C}$ under a $16 \mathrm{~h}: 8 \mathrm{~h}$ light: dark cycle. Pupae were separated by sex and placed in different jars. The third day after they emerged, 30 pheromone glands [58, 80] and abdominal epidermal tissue [6] from 3 individuals of female moths were dissected 3-4 h into scotophase [81] and stored in $-80{ }^{\circ} \mathrm{C}$ freezer until RNA extraction.

\section{RNA extraction}

Total RNA from pheromone gland and abdominal tissue were extracted using the TRIzol reagent (Life 


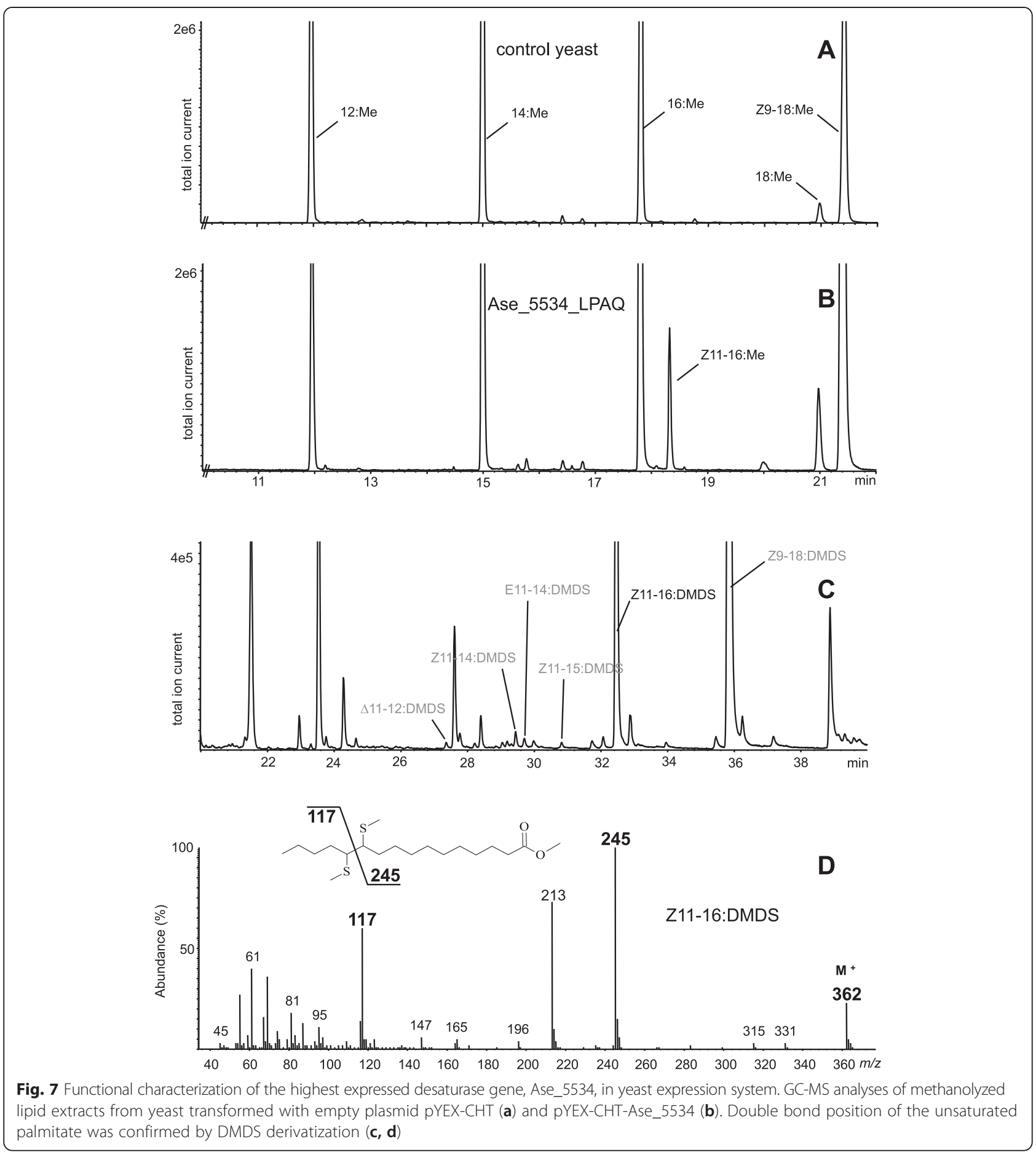

Technologies, Lidingö, Sweden) according to the manufacturer's instructions except for three additional ethanol washes before dissolving RNA in water. RNA concentration and purity were checked on NanoDrop2000 (Thermo Scientific, Saveen Werner, Malmö, Sweden).

\section{Illumina sequencing and bioinformatic analysis}

Twenty $\mu \mathrm{g}$ of total RNA from each sample were sent to BGI (Hong Kong Co., Ltd) for library construction, Illumina sequencing and subsequent bioinformatic analysis.

Reads were assembled using Trinity [82] into contigs. Then the reads are mapped back to contigs, get sequences 
Table 5 The gene candidates found in As_PG that may be involved in p-oxidation processes

\begin{tabular}{|c|c|c|c|c|c|}
\hline genelD & GenBank accession & As PG FPKM & As AB FPKM & Swissprot-annotation & ko_definition \\
\hline \multicolumn{6}{|l|}{ acyl-CoA dehydrogenase } \\
\hline Unigene5337_All & KJ622076 & 2.49 & 0.93 & $\begin{array}{l}\text { Short-chain specific acyl-CoA } \\
\text { dehydrogenase }\end{array}$ & butyryl-CoA dehydrogenase[EC:1.3.8.1] \\
\hline Unigenel8315_All & KJ622077 & 4.35 & 3.26 & $\begin{array}{l}\text { Short-chain specific acyl-CoA } \\
\text { dehydrogenase }\end{array}$ & butyryl-CoA dehydrogenase[EC:1.3.8.1] \\
\hline CL3917.Contigl_All & KJ622078 & 8.02 & 14.14 & $\begin{array}{l}\text { Short-chain specific acyl-CoA } \\
\text { dehydrogenase }\end{array}$ & butyryl-CoA dehydrogenase[EC:1.3.8.1] \\
\hline Unigenel5571_All & KJ622079 & 24.39 & 67.70 & $\begin{array}{l}\text { Short/branched chain specific } \\
\text { acyl-CoA dehydrogenase }\end{array}$ & $\begin{array}{l}\text { short/branched chain acyl-CoA } \\
\text { dehydrogenase [EC:1.3.99.12] }\end{array}$ \\
\hline CL 1315 .Contig2_All & KJ622080 & 29.09 & 40.69 & $\begin{array}{l}\text { Probable medium-chain specific } \\
\text { acyl-CoA dehydrogenase }\end{array}$ & acyl-CoAdehydrogenase [EC: 1.3.99.3] \\
\hline Unigene4168_All & KJ622081 & 4.04 & 3.43 & $\begin{array}{l}\text { Acyl-CoA dehydrogenase family } \\
\text { member } 9\end{array}$ & $\begin{array}{l}\text { Acyl-CoA dehydrogenase family } \\
\text { member } 9 \text { [EC:1.3.99.-] }\end{array}$ \\
\hline CL252.Contigl_All & KJ622082 & 10.03 & 7.93 & $\begin{array}{l}\text { Very long-chain specific acyl-CoA } \\
\text { dehydrogenase }\end{array}$ & $\begin{array}{l}\text { Very long chain acyl-CoA dehydrogenase } \\
\text { [EC:1.3.99.-] }\end{array}$ \\
\hline CL622.Contig4_All & KJ579211 & 77.52 & 107.57 & $\begin{array}{l}\text { Trifunctional enzyme subunit } \\
\text { beta }\end{array}$ & acetyl-CoAacyltransferase [EC:2.3.1.16] \\
\hline Unigene7769_All & KJ622083 & 3.29 & 2.51 & Isovalery|-CoA dehydrogenase & $\begin{array}{l}\text { Isovaleryl-CoA dehydrogenase } \\
\text { [EC:1.3.8.4] }\end{array}$ \\
\hline Unigene9593_All & KJ622084 & 8.77 & 9.31 & |sovalery|-CoA dehydrogenase & $\begin{array}{l}\text { Isovaleryl-CoA dehydrogenase } \\
\text { [EC:1.3.8.4] }\end{array}$ \\
\hline \multicolumn{6}{|l|}{ acyl-CoA oxidase } \\
\hline CL3960.Contigl_All & KJ622085 & 16.52 & 17.33 & $\begin{array}{l}\text { Probable peroxisomal acyl-CoA } \\
\text { oxidase }\end{array}$ & acyl-CoA oxidase [EC:1.3.3.6] \\
\hline CL4327.Contigl_All & KJ622086 & 3.85 & 4.30 & Peroxisomal acyl-CoA oxidase & acyl-CoA oxidase [EC:1.3.3.6] \\
\hline CL6898.Contigl_All & KJ622087 & 5.75 & 11.79 & $\begin{array}{l}\text { Probable peroxisomal acyl-CoA } \\
\text { oxidase } 1\end{array}$ & acyl-CoA oxidase [EC:1.3.3.6] \\
\hline CL7062.Contigl_All & KJ622088 & 14.54 & 18.14 & Peroxisomal acyl-CoA oxidase 3 & acyl-CoA oxidase [EC:1.3.3.6] \\
\hline Unigenel 9521_All & KJ622089 & 29.25 & 23.07 & $\begin{array}{l}\text { Probable peroxisomal acyl-CoA } \\
\text { oxidase } 1\end{array}$ & acyl-CoA oxidase [EC:1.3.3.6] \\
\hline Unigene26088_All & KJ622090 & 2.29 & 0.68 & Peroxisomal acyl-CoA oxidase 1 & acyl-CoA oxidase [EC:1.3.3.6] \\
\hline Unigene33961_All & KJ622091 & 3.46 & 2.66 & $\begin{array}{l}\text { Probable peroxisomal acyl-CoA } \\
\text { oxidase } 1\end{array}$ & acyl-CoA oxidase [EC:1.3.3.6] \\
\hline Unigene4386_All & KJ622092 & 1.74 & 1.78 & $\begin{array}{l}\text { Probable peroxisomal acyl-CoA } \\
\text { oxidase } 1\end{array}$ & acyl-CoA oxidase [EC:1.3.3.6] \\
\hline Unigene5059_All & KJ622093 & 1.92 & 1.13 & Peroxisomal acyl-CoA oxidase 1 & acyl-CoA oxidase [EC:1.3.3.6] \\
\hline Unigene6715_A11 & KJ622094 & 386.08 & 4.64 & $\begin{array}{l}\text { Probable peroxisomal acyl-CoA } \\
\text { oxidase } 1\end{array}$ & acyl-CoA oxidase [EC:1.3.3.6] \\
\hline \multicolumn{6}{|l|}{ enoyl-CoA hydratase } \\
\hline CL1656.Contigl_All & KJ622095 & 16.69 & 23.69 & Methylglutaconyl-CoA hydratase & $\begin{array}{l}\text { Methylglutaconyl-CoA hydratase } \\
\text { [EC:4.2.1.18] }\end{array}$ \\
\hline CL2503.Contigl_All & KJ622096 & 8.85 & 1.87 & Probable enoyl-CoA hydratase & enoyl-CoA hydratase [EC:4.2.1.17] \\
\hline CL2595.Contigl_All & KJ622097 & 122.91 & 142.29 & $\begin{array}{l}\text { Trifunctional enzyme subunit } \\
\text { alpha }\end{array}$ & enoyl-CoA hydratase [EC:4.2.1.17] \\
\hline Unigenel4514_All & KJ622098 & 4.15 & 4.35 & $\begin{array}{l}\text { 3-hydroxyisobutyryl-CoA } \\
\text { hydrolase }\end{array}$ & $\begin{array}{l}\text { 3-hydroxyisobutyryl-CoA hydrolase } \\
\text { [EC:3.1.2.4] }\end{array}$ \\
\hline Unigenel7624_All & KJ622099 & 73.15 & 87.01 & Enoyl-CoA hydratase & enoyl-CoA hydratase [EC:4.2.1.17] \\
\hline Unigene6308_All & KJ622100 & 5.00 & 5.89 & $\begin{array}{l}\text { Enoyl-CoA hydratase } \\
\text { domain-containing protein } 3\end{array}$ & enoyl-CoA hydratase [EC:4.2.1.17] \\
\hline \multicolumn{6}{|l|}{$\begin{array}{l}\text { L-3-hydroxyacyl-CoA } \\
\text { dehydrogenase }\end{array}$} \\
\hline Unigenel2153_All & KJ622101 & 11.64 & 1.60 & & \\
\hline
\end{tabular}


Table 5 The gene candidates found in As_PG that may be involved in p-oxidation processes (Continued)

\begin{tabular}{|c|c|c|c|c|c|}
\hline & & & & $\begin{array}{l}\text { 3-hydroxyacyl-CoA } \\
\text { dehydrogenase }\end{array}$ & $\begin{array}{l}\text { 3-hydroxyacyl-CoA dehydrogenase } \\
\text { [EC1.1.1.35] }\end{array}$ \\
\hline Unigenel5615_All & KJ622102 & 8.46 & 8.38 & $\begin{array}{l}\text { 3-hydroxyacyl-CoA } \\
\text { dehydrogenase }\end{array}$ & $\begin{array}{l}\text { 3-hydroxyacyl-CoA dehydrogenase } \\
\text { [EC1.1.1.35] }\end{array}$ \\
\hline Unigenel7583_All & KJ622103 & 174.80 & 83.79 & $\begin{array}{l}\text { Peroxisomal multifunctional } \\
\text { enzyme }\end{array}$ & $\begin{array}{l}\text { 3-hydroxyacyl-CoA dehydrogenase } \\
\text { [EC1.1.1.35] }\end{array}$ \\
\hline Unigenel9554_All & KJ622104 & 103.82 & 78.74 & Flydroxyacyl-CoA dehydrogenase & $\begin{array}{l}\text { 3-hydroxyacyl-CoA dehydrogenase } \\
\text { [EC1.1.1.35] }\end{array}$ \\
\hline Unigene8215_All & KJ622105 & 8.18 & 4.22 & $\begin{array}{l}\text { Probable 3-hydroxyacyl-CoA } \\
\text { dehydrogenase }\end{array}$ & $\begin{array}{l}\text { 3-hydroxyacyl-CoA dehydrogenase } \\
\text { [EC1.1.1.35] }\end{array}$ \\
\hline \multicolumn{6}{|l|}{ 3-ketoacyl-CoA thiolase } \\
\hline CL2371.Contigl_All & KJ579207 & 10.01 & 5.43 & 3-ketoacyl-CoA thiolase & acetyl-CoA acyltransferase 2 [EC:2.3.1.16] \\
\hline Unigene21478_A11 & KJ622106 & 4.47 & 0.05 & 3-ketoacyl-CoA thiolase & acetyl-CoA acyltransferase 2 [EC:2.3.1.16] \\
\hline Unigene26739_All & KJ622107 & 3.32 & 0.00 & 3-ketoacyl-CoA thiolase & acetyl-CoA acyltransferase 2 [EC:2.3.1.16] \\
\hline Unigene28250_All & KJ622108 & 122.89 & 42.24 & $\begin{array}{l}\text { Trifunctional enzyme subunit } \\
\text { beta }\end{array}$ & acetyl-CoA acyltransferase [EC:2.3.1.16] \\
\hline Unigene30699_All & KJ622109 & 1.19 & 0.76 & 3-ketoacyl-CoA thiolase & acetyl-CoA acyltransferase 2 [EC:2.3.1.16] \\
\hline Unigene5444_All & KJ622110 & 2.35 & 15.28 & 3-ketoacyl-CoA thiolase & acetyl-CoA acyltransferase 2 [EC:2.3.1.16] \\
\hline \multicolumn{6}{|l|}{$\begin{array}{l}\mathrm{A} 3, \mathrm{~A} 2 \text {-trans-enoyl-CoA } \\
\text { isomerase }\end{array}$} \\
\hline CL3311.Contigl_All & KJ622111 & 24.40 & 35.52 & Enoyl-CoA delta isomerase 1 & $\begin{array}{l}\text { 3,2-trans-enoyl-CoAisomerase, } \\
\text { mitochondrial [EC:5.3.3.8] }\end{array}$ \\
\hline Unigene2565_All & KJ622112 & 3.56 & 1.88 & Enoyl-CoA delta isomerase 2 & $\begin{array}{l}\text { peroxisomal 3,2-trans-enoyl-CoA } \\
\text { isomerase [EC:5.3.3.8] }\end{array}$ \\
\hline \multicolumn{6}{|l|}{$\begin{array}{l}\Delta 3,5 \Delta 2,4-\text { dienoyl-CoA } \\
\text { isomerase }\end{array}$} \\
\hline Unigenel6713_All & KJ622113 & 11.43 & 18.26 & $\begin{array}{l}\text { Delta(3,5)-Delta(2,4)-dienoy 1-Co } \\
\text { A is omerase }\end{array}$ & $\begin{array}{l}\text { delta(3,5)-Delta(2,4)-dienoyl-CoA } \\
\text { isomerase [EC:5.3.3.-] }\end{array}$ \\
\hline
\end{tabular}

without Ns and cannot be extended on either end. Such sequences are defined as unigenes. Then TGICL [83] is used to assemble all the unigenes from As_PG and As_AB to form a single set of non-redundant unigenes. Then gene family clustering was performed and unigenes were divided to two classes. One is clusters, which the prefix is $\mathrm{CL}$ and the cluster id is behind. In one cluster, there are several unigenes which similarity between them is more than $70 \%$. The other is singletons, which the prefix is unigene. Unigene sequences are aligned with blastdb using blastx (E-value $<0.00001)$. Sequence orientations are determined according to the best hit in the database. Bioinformatic data were viewed and further processed using Geneious version (6.1.6), created by Biomatters and available from http://www.geneious.com.

The calculation of unigene expression was performed using the FPKM method (Fragments Per kb per Million fragments) $[84,85]$, the formula is $\mathrm{FPKM}=10^{6} \mathrm{C} / \mathrm{NL} /$ $10^{3}$. Set FPKM to be the expression of unigene $\mathrm{A}$, and $\mathrm{C}$ to be number of fragments that uniquely aligned to unigene $\mathrm{A}, \mathrm{N}$ to be total number of fragments that uniquely aligned to all unigenes, and $\mathrm{L}$ to be the base number in the CDS of unigene A. The FPKM method eliminates the influence of different gene lengths and sequencing levels on the calculation of gene expression. Therefore the calculated gene expression can be directly used for comparing the differences in gene expression between samples [85].

Functional annotations of unigenes were conducted, based on protein sequence similarity, towards the KEGG Pathway, COG [86] and Gene Ontoloty (GO) databases. Briefly, we search all unigene sequences against protein databases (NR, SwissProt, KEGG, COG) using blastx (E-value $<0.00001)$. Based on NR annotation, we use Blast2GO program [44] to get GO annotation of all unigenes. After getting GO annotation for every unigene, we use WEGO software [87] to do GO functional classification for all unigenes.

\section{Phylogenetic reconstruction}

Sequences used for phylogenetic reconstructions were retrieved from the GenBank (http://www.ncbi.nlm.nih.gov) database. Neighbor-Joining trees were constructed using Mega version 4.0 [88]. Briefly, multiple sequence alignments were run using the MAFFT (online version) and the output FASTA format data were plugged 


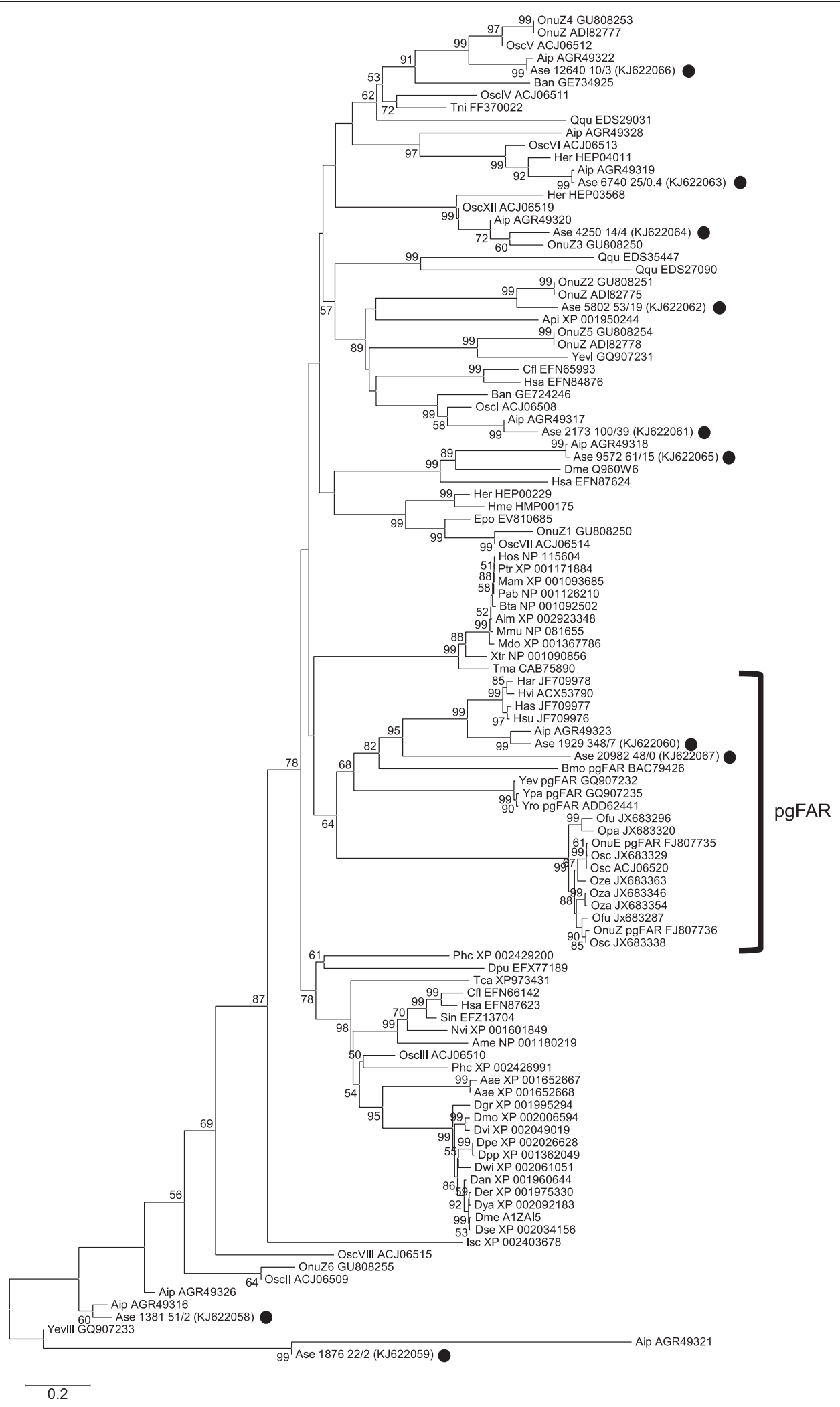

Fig. 8 Phylogenetic relationship of FARs from arthropods, mammals and lepidoptera constructed using amino acid sequences. The pgFAR clade is marked by a black bracket, which contains previously studied functional FARs involved in moth pheromone biosynthesis. FARs identified in this study are displayed by black dots, with As_PG_FPKM and As_AB_FPKM indicated 

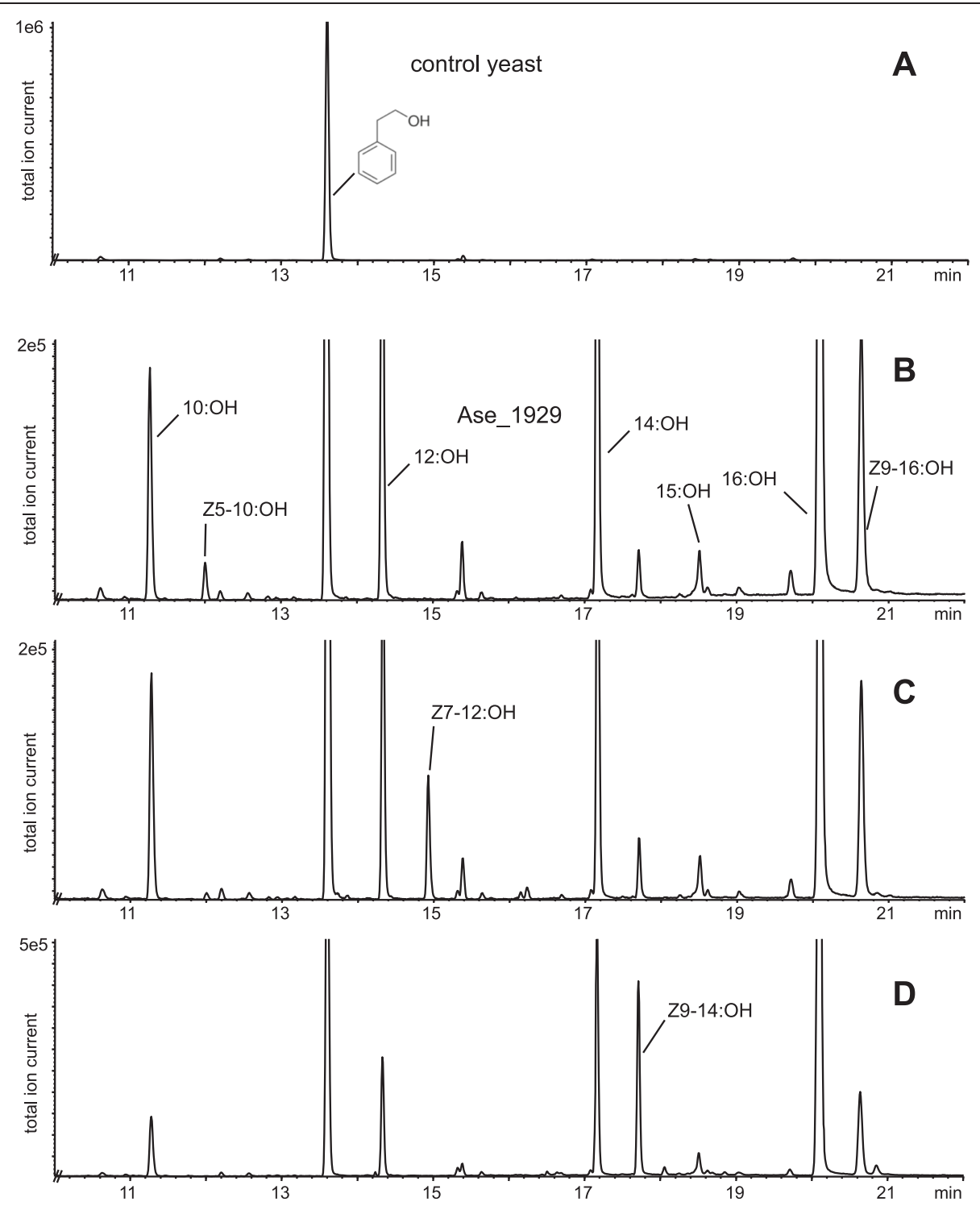

Fig. 9 Functional assay of the highest expressed FAR in As_PG, Ase_1929 identified in this study. GC trace of hexane extract of yeast transformed by empty plasmid (a) and pYES2_CL1929 supplemented with Z5-10:Me (b), Z7-12:Me (c), Z9-14:Me (d). The control yeast produced no fatty alcohols whereas the yeast expressing Ase_1929 convert a series of fatty acids into their corresponding fatty alcohols (b-d)

into Mega software. Genetic distance model was JTT, 1500 replicates, Neighbor-Joining as tree building method.

\section{Fatty acid precursors}

Z9-18:Me, 16:Me were purchased from Larodan Fine Chemicals AB (Malmö, Sweden). Z5-10:OH, Z7-12:OH, Z9-14:OH were purchased from Pherobank (Wageningen, The Netherlands, 98 \% purity). Z9-14:Me, Z7-12:Me, Z510:Me were prepared from their corresponding alcohols by previously described methods [89]. All FAMEs and $\mathrm{OH}$ were dissolved in $96 \%$ ethanol in a $0.1 \mathrm{M}$ stock solution. All alcohols used as reference compounds were from our laboratory collection of pheromone compounds.

\section{Construction of expression vector for functional assay}

For the construction of yeast expression vectors containing the candidate genes, specific primers with attB1 and attB2 sites incorporated were designed for amplifying the ORF of genes of interest. The PCR products were subjected to agarose gel electrophoresis and purified using the Wizard ${ }^{\circ}$ SV Gel and PCR Clean up system (Promega Biotech AB, Nacka, Sweden). The ORFs were subcloned into the pDONR221 vector in presence of BP 
Table $\mathbf{6}$ List of tested acetyltransferases that are generated by annotations and by Blastx of As_PG library with previously published ([54, 55] and references therein) promising candidates as queries

\begin{tabular}{|c|c|c|c|c|c|c|c|c|c|}
\hline Gene object & Accession code & bp & As PG FPKM & As AB FPKM & $\mathrm{Nr}$ annotation & KO/COG/GO/Swissprot annotation & Species & Accession number & $\%$ Identity \\
\hline CL1935 & KJ579206 & 1542 & 53.53 & 70.39 & Acetyl-CoA acetyltransferase & aeetyl-CoA C-aeetyltransferase [EC:2.3.1.9] & Danaus plexippus & EHJ68573 & 82 \\
\hline CL2371 & KJ579207 & 1203 & 14.63 & 8.51 & Thiolase 4 & aeetyl-CoAacyltransferase 2 [EC:2.3.1.16] & Heliothis virescens & AGG55002 & 92 \\
\hline CL2825 & KJ579208 & 771 & 6.38 & 14.16 & Hypothetical protein KGM 16,501 & Predicted acetyltransferases and hydrolases & Danaus plexippus & EHJ72951 & 87 \\
\hline CL3492 & KJ579209 & 2094 & 16.48 & 10.62 & Crooked neck protein & $\begin{array}{l}\text { peptide alpha-N-acetyltransferase } \\
\text { [EC:2.3.1.88] }\end{array}$ & Aedes aegypti & XP001653815 & 83 \\
\hline CL5827 & KJ579210 & 1608 & 682.84 & 198.28 & $\begin{array}{l}\text { Sterol carrier protein 2/3- oxoacyl-CoA } \\
\text { thiolase }\end{array}$ & Sterol carrier protein 2 [EC:2.3.1.176] & Spodoptera littoralis & AAT72922 & 94 \\
\hline CL622 & KJ579211 & 1425 & 146.13 & 113.81 & $\begin{array}{l}\text { Fatty acid beta-oxidation complex } \\
\text { subunit beta }\end{array}$ & acetyl-CoA acyltransferase [EC:2.3.1.16] & Heliothis virescens & ADB57045 & 95 \\
\hline CL7064 & KJ579212 & 543 & 76.93 & 186.14 & Acetyltransferase & $\begin{array}{l}\text { Peptide alpha-N-acetyltransferase } \\
\text { [EC:2.3.1.88] }\end{array}$ & Agrotis ipsilon & AGQ45625 & 100 \\
\hline Unigenel520 & KJ579213 & 1191 & 136.8 & 89.85 & Thiolase 1 & aeetyl-CoA acyltransferase 2 [EC:2.3.1.16] & Heliothis virescens & AGG54999 & 93 \\
\hline Unigene5444 & KJ579214 & 1113 & 2.35 & 15.28 & Thiolase 3 & aeetyl-CoA acyltransferase 2 [EC:2.3.1.16] & Heliothis virescens & AGG55001 & 80 \\
\hline Unigene7635 & KJ579215 & 891 & 23.37 & 46.32 & $\begin{array}{l}\text { Palmitoyl-protein thioesterase } 1 \text { like } \\
\text { isoform XI }\end{array}$ & $\begin{array}{l}\text { Predicted acetyltransferases and } \\
\text { hydrolases }\end{array}$ & Bombyx mori & XP004931556 & 73 \\
\hline Unigene8748 & KJ579216 & 549 & 13.51 & 9.31 & Dynactin 4 protein & $\begin{array}{l}\text { Carbonic anhydrases/acetyltransferases, } \\
\text { isoleucine patch superfamily }\end{array}$ & Bombyx mori & NP001040117 & 99 \\
\hline CL197 & KJ579217 & 1080 & 20.88 & 20.02 & Monoacylglycerol acyl transferase & $\begin{array}{l}\text { 2-acylglycerol O-acyltransferase } 2 \\
\text { [EC:2.3.1.22] }\end{array}$ & Manduca sexta & AHH25136 & 72 \\
\hline CL2038 & KJ579218 & 1443 & 5.54 & 30.82 & Transmembrane protein nessy & $\begin{array}{l}\text { lysophospholipid acyltransferase } 5 \\
\text { [EC:2.3.1.23 2.3.1.-] }\end{array}$ & Bombyx mori & XP004933932 & 76 \\
\hline CL2800 & KJ579219 & 1638 & 20.71 & 27.68 & $\begin{array}{l}\text { Dihydroxyacetone phosphate } \\
\text { acyltransferase }\end{array}$ & $\begin{array}{l}\text { glyceronephosphate O-acyltransferase } \\
\text { [EC:2.3.1.42] }\end{array}$ & Bombyx mori & XP004921835 & 64 \\
\hline Unigene21478 & KJ579220 & 540 & 4.47 & 0.05 & Thiolase 2 & aeetyl-CoA acyltransferase 2 [EC:2.3.1.16] & Heliothis virescens & AGG55000 & 73 \\
\hline Unigene2251 & KJ579221 & 819 & 1.54 & 0.17 & Acetyltransferase & $\begin{array}{l}\text { lysophosphatidate acyltransferase } \\
\text { [EC:2.3.1.51] }\end{array}$ & Agrotis ipsilon & AGQ45623 & 97 \\
\hline Unigene4319 & KJ579222 & 1152 & 7.58 & 11.83 & Acyltransferase AGPAT6 & $\begin{array}{l}\text { lysophosphatidic acid acyltransferase/ } \\
\text { [EC:2.3.1.51] }\end{array}$ & Heliothis virescens & AGG54998 & 96 \\
\hline CL3297 & KJ579223 & 1296 & 12.72 & 12.03 & Endophilin-A-like isoform XI & Endophilin-A & Bombyx mori & XP004929694 & 86 \\
\hline CL3384 & KJ579224 & 1269 & 69.16 & 84.67 & Ipase 1-like & Predicted hydrolases or acyltransferases & Bombyx mori & XP004927335 & 57 \\
\hline CL3414 & KJ579225 & 1428 & 7.08 & 16.56 & Sterol O-acyltransferase 1 & Sterol O-aeyltransferase [EC:2.3.1.26] & Danaus plexippus & EHJ66395 & 66 \\
\hline CL3666 & KJ579226 & 1272 & 38.77 & 53.18 & $\begin{array}{l}\text { Putative glycerol-3-phosphate } \\
\text { acyltransferase }\end{array}$ & type I keratin, acidic & Danaus plexippus & EHJ77802 & 56 \\
\hline CL3797 & KJ579227 & 1164 & 10.06 & 4.91 & Hypothetical protein KGM19212 & {$[E C: 2.3 .1 .-]$} & Danaus plexippus & EHJ67359 & 73 \\
\hline CL5775 & KJ579228 & 1179 & 22.36 & 14.42 & $\begin{array}{l}\text { I-acylglycerol-3-phosphate } \\
\text { O- acyltransferase ABHD5 }\end{array}$ & $\begin{array}{l}\text { abhydrolase domain-containing protein } \\
5 \text { [EC:2.3.1.51] }\end{array}$ & Bombyx mori & XP004927229 & 85 \\
\hline
\end{tabular}


Table 6 List of tested acetyltransferases that are generated by annotations and by Blastx of As_PG library with previously published ([54, 55] and references therein) promising candidates as queries (Continued)

\begin{tabular}{|c|c|c|c|c|c|c|c|c|c|}
\hline CL6732 & KJ579229 & 1071 & 7.31 & 8.66 & Epoxide hydrolase 4-like protein & Soluble epoxide hydrolase [EC:3.3.2.10] & Heliconius erato & AGC92732 & 66 \\
\hline CL8534 & KJ579230 & 1410 & 157.51 & 175.16 & $\begin{array}{l}\text { Dihydrolipoamide succinyltransferase } \\
\text { component of 2-oxoglutarate } \\
\text { dehydrogenase, partial }\end{array}$ & $\begin{array}{l}\text { 2-oxoglutarate dehydrogenase } \\
\text { E2 component (dihydrolipoamide } \\
\text { succinyltransferase) [EC:2.3.1.61] }\end{array}$ & Papilio polytes & BAM20532 & 93 \\
\hline CL8651 & KJ579231 & 675 & 99.26 & 87.58 & Hypothetical protein KGM 17,353 & $\begin{array}{l}\text { Pyruvate dehydrogenase E2 component } \\
\text { (dihydrolipoamide acetyltransferase) } \\
\text { [EC:2.3.1.12] }\end{array}$ & Danaus plexippus & EHJ75541 & 75 \\
\hline CL914 & KJ579232 & 1962 & 19.4 & 17.94 & Carnitine o-acyltransferase & $\begin{array}{l}\text { Carnitine O-palmitoyltransferase } 2 \\
\text { [EC:2.3.1.21] }\end{array}$ & Bombyx mori & XP004929482 & 75 \\
\hline CL9375 & KJ579233 & 2073 & 16.36 & 9.35 & $\begin{array}{l}\text { Juvenile hormone epoxide } \\
\text { hydrolase-like protein } 3\end{array}$ & Predicted hydrolases or acyltransferases & Bombyx mori & NP001159619 & 60 \\
\hline Unigenel0654 & KJ579234 & 1440 & 10.41 & 5.11 & Lipoamide acyltransferase & $\begin{array}{l}\text { 2-oxoisovalerate dehydrogenase E2 } \\
\text { component (dihydrolipoyl transacylase) } \\
\text { [EC:2.3.1.168] }\end{array}$ & Bombyx mori & XP004926652 & 71 \\
\hline Unigenel5439 & KJ579235 & 924 & 0.58 & 6.57 & Serine hydrolase-like protein 2- like & [EC:3.1..--] & Bombyx mori & XР004926488 & 55 \\
\hline Unigene6166 & KJ579236 & 1446 & 5.56 & 27.08 & Glycerol-3-phosphate acyltransferase 4 & $\begin{array}{l}\text { Glycerol-3-phosphate O-acyltransferase } \\
\text { 3/4 [EC:2.3.1.15] }\end{array}$ & Bombyx mori & XP004925117 & 84 \\
\hline Unigene7548 & KJ579237 & 996 & 15.04 & 13.97 & Probable serine hydrolase-like & $\begin{array}{l}\text { Predicted hydrolases or acyltransferases } \\
\text { (alpha/beta hydrolase superfamily) }\end{array}$ & Bombyx mori & XР004924867 & 70 \\
\hline Unigene7854 & KJ579238 & 522 & 3.92 & 1.09 & acyltransferase AGPAT5 & $\begin{array}{l}\text { Lysophosphatidate acyltransferase } \\
\text { [EC:2.3.1.51] }\end{array}$ & Heliothis virescens & AGG54997 & 83 \\
\hline Unigene8703 & KJ579239 & 1200 & 3.71 & 3.53 & $\begin{array}{l}\text { Lysophospholipid acyltransferase } \\
\text { 1-like }\end{array}$ & $\begin{array}{l}\text { Lysophospholipid acyltransferase } 1 / 2 \\
\text { [EC:2.3.1.51 2.3.1.-] }\end{array}$ & Bombyx mori & XP004927037 & 74 \\
\hline
\end{tabular}




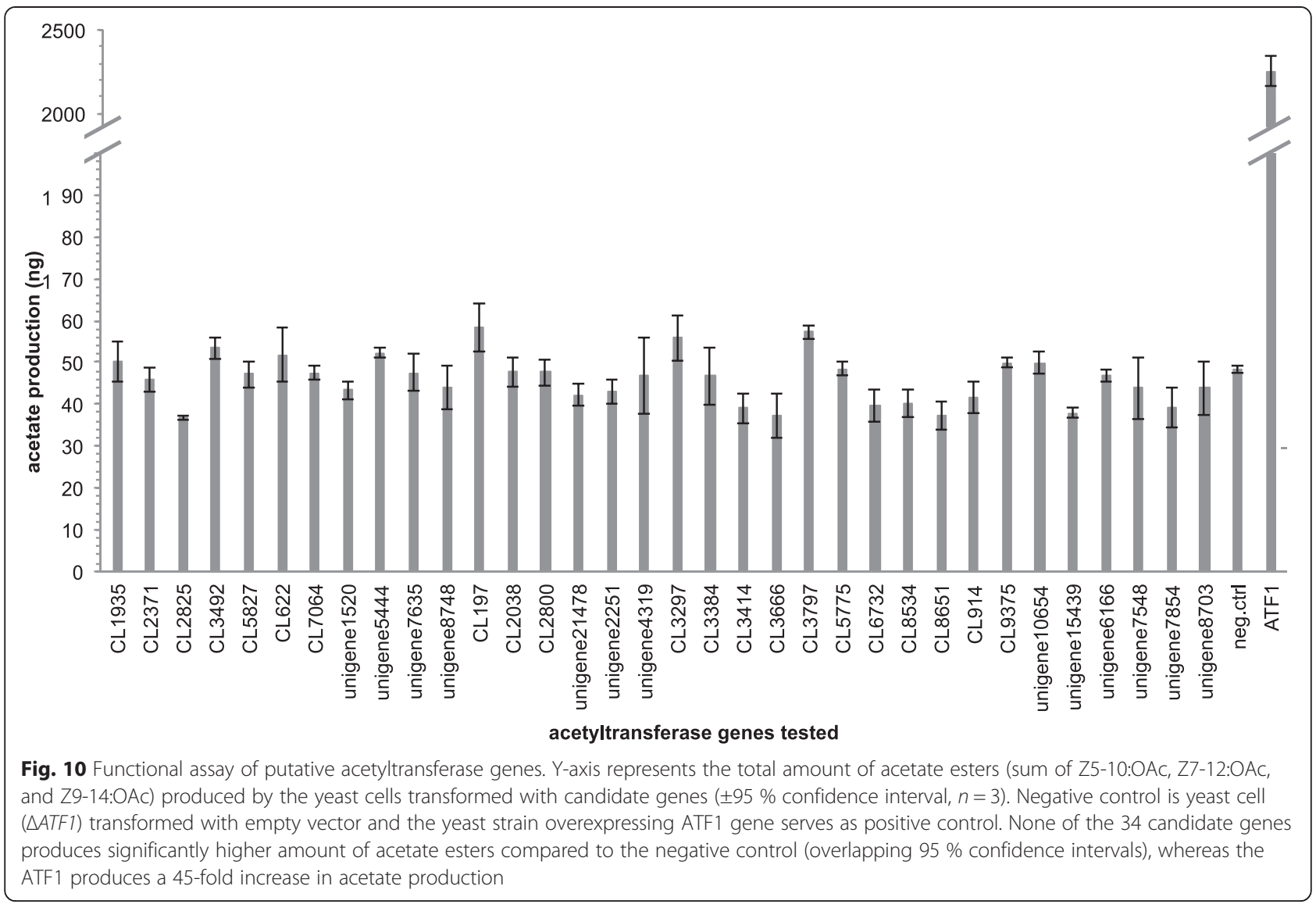

clonase (Life Technologies), after confirmation by sequencing, the correct entry clones were selected and do LR reaction with pYES2-DEST52 (for FARs and acetyltransferases) or pYEX-CHT-DEST vector (for desaturases), and resulting expression clones were analyzed by sequencing.

\section{Functional assay in yeast}

The resultant recombinant expression vectors harboring the candidate genes were introduced into the INVSc (MATa HIS3 LEU2 trp1-289 ura3-52) (for FARs), the $\triangle A T F 1$ knockout strain (for acetyltransferase), or the double deficient ole1 elo1 strain (MATa elo1::HIS3 ole1::LEU2 ade2 his3 leu2 ura3) (for desaturase) of the yeast Saccharomyces cerevisiae [19] using the S.c. easy yeast transformation kit (Life Technologies). For selection of uracil (and leucine) prototrophs, the transformed yeast was allowed to grow on SC plate containing $0.7 \%$ YNB (w/o aa, with Ammonium sulfate) and a complete dropout medium lacking uracil (and leucine) (Formedium ${ }^{\mathrm{Tm}}$ LTD, Norwich, England), 2 \% glucose, $1 \%$ tergitol (type Nonidet NP-40, Sigma-Aldrich Sweden AB, Stockholm, Sweden), $0.01 \%$ adenine (Sigma) and containing $0.5 \mathrm{mM}$ oleic acid (Sigma) as extra fatty acid source. After 2 days (7 days for ole1 elo1 strain) at $30{ }^{\circ} \mathrm{C}$, individual colonies were picked up to inoculate $10 \mathrm{~mL}$ selective medium at $30{ }^{\circ} \mathrm{C}$ and grown at $300 \mathrm{rpm}$ for $48 \mathrm{~h}$. Yeast cultures were diluted to an OD600 of 0.4 in $10 \mathrm{~mL}$ fresh selective medium containing $2 \%$ galactose $\left(2 \mathrm{mM} \mathrm{CuSO}_{4}\right)$ with supplementation of a biosynthetic precursor. Each FAME or fatty alcohol precursor was prepared at a concentration of $100 \mathrm{mM}$ in $96 \%$ ethanol and added to reach a final concentration of $0.5 \mathrm{mM}$ in the culture medium [19]. In the acetyltransferase assay the yeasts were supplemented with a mixture of the three alcohols $\mathrm{Z} 9-14: \mathrm{OH}, \mathrm{Z7}-12: \mathrm{OH}$ and $\mathrm{Z} 5-10: \mathrm{OH}$. Yeasts were cultured in $30^{\circ} \mathrm{C}$ in a shaking incubator at $30{ }^{\circ} \mathrm{C}$.

\section{Fatty acid/alcohol/acetate analysis}

After $48 \mathrm{~h}$ of incubation yeast cells were harvested by centrifugation at 3,000 rpm. For the analysis of desaturase products, total lipids were extracted using $3.75 \mathrm{~mL}$ of methanol/chloroform $(2: 1, \mathrm{v} / \mathrm{v})$, in a glass tube. One $\mathrm{mL}$ of HAc $(0.15 \mathrm{M})$ and $1.25 \mathrm{~mL}$ of water were added to the tube to wash the chloroform phase. Tubes were vortexed vigorously and centrifuged at 
$2000 \mathrm{rpm}$ for $2 \mathrm{~min}$. The bottom chloroform phase, about $1 \mathrm{~mL}$, containing the total lipids, were transferred to a new glass tube. Fatty acid methylesters (FAMEs) were made from this total lipid extract. The solution of total lipids was evaporated to dryness under gentle nitrogen flow. One $\mathrm{mL}$ of sulfuric acid ( $2 \%$ in methanol) was added to the tube, which was then vortexed vigorously and incubated at $90{ }^{\circ} \mathrm{C}$ for an hour. After incubation, $1 \mathrm{~mL}$ of water was added, mixed well, and then $1 \mathrm{~mL}$ of hexane was used to extract the FAMEs [10].

Fatty alcohols and acetates were extracted from cells using $800 \mu \mathrm{L}$ of hexane plus sonication. After brief centrifugation, the supernatant was transferred to a new tube and subjected to GC-MS analysis.

Double bond positions were confirmed by dimethyl disulfide (DMDS) derivatization [13], followed by GC-MS analysis. FAMEs $(50 \mu \mathrm{L})$ were transferred to a new tube and $50 \mu \mathrm{L}$ DMDS was added and incubated at $40{ }^{\circ} \mathrm{C}$ overnight, in the presence of $5 \mu \mathrm{L}$ of iodine ( $5 \%$ in diethyl ether) as catalyst. Hexane $(200 \mu \mathrm{L})$ was added to the sample and the reaction was neutralized by addition of $50-100 \mu \mathrm{L} \mathrm{Na} \mathrm{S}_{2} \mathrm{O}_{3}$ (5\% in water). The organic phase was recovered and concentrated under a gentle nitrogen stream to $40-50 \mu \mathrm{L}$.

\section{Gas chromatography - mass spectrometry (GC-MS)}

The methylesters, fatty alcohols and acetates were subjected to GC-MS analyses on a Hewlett Packard 6890 GC coupled to a mass spectrometer HP 5973. The GC was equipped with an INNOWax column $(30 \mathrm{~m} \times 0.25 \mathrm{~mm}$ i.d. $\times 0.25 \mu \mathrm{m}$ film thickness, Agilent Technologies), and helium was used as carrier gas (average velocity: $33 \mathrm{~cm} / \mathrm{s}$ ). The MS was operated in electron impact mode $(70 \mathrm{eV})$, scaning between $\mathrm{m} / \mathrm{z} 30$ and $\mathrm{m} / \mathrm{z} 400$, and the injector was configured in splitless mode at $220{ }^{\circ} \mathrm{C}$. The oven temperature was set to $80^{\circ} \mathrm{C}$ for $1 \mathrm{~min}$, then increased at a rate of $10^{\circ} \mathrm{C} / \mathrm{min}$ up to $210{ }^{\circ} \mathrm{C}$, followed by a hold at $210{ }^{\circ} \mathrm{C}$ for $15 \mathrm{~min}$, and then increased at a rate of $10^{\circ} \mathrm{C} /$ min up to $230^{\circ} \mathrm{C}$ followed by a hold at $230{ }^{\circ} \mathrm{C}$ for $20 \mathrm{~min}$.

DMDS derivatives were analyzed on an Agilent 6890 GC system equipped with HP-5MS capillary column $(30 \mathrm{~m} \times 0.25 \mathrm{~mm}$ i.d. $\times 0.25 \mu \mathrm{m}$ film thickness, Agilent Technologies) coupled with an HP 5973 mass spectrometer. The oven temperature was set at $80{ }^{\circ} \mathrm{C}$ for $1 \mathrm{~min}$, raised to $140{ }^{\circ} \mathrm{C}$ at a rate of $20{ }^{\circ} \mathrm{C} / \mathrm{min}$, then to $250{ }^{\circ} \mathrm{C}$ at a rate of $4{ }^{\circ} \mathrm{C} / \mathrm{min}$ and held for $20 \mathrm{~min}$ [11].

Data were analyzed using the ChemStation software (Agilent, Technologies, USA).

\author{
Accession code \\ PBANr: KJ622075 \\ ACC: KJ622074 \\ FAS: KJ622068-KJ622073 \\ Desaturases: KJ622048-KJ622057
}

$\beta$-oxidation enzymes: KJ622076-KJ622113

FARs: KJ622058-KJ622067

Acetyltransferases: KJ579206-KJ579239

\section{Abbreviations}

ACC: Acetyl-CoA carboxylase; FAS: fatty acid synthase; FAR: fatty-acyl reductase; GC-MS: gas chromatography mass spectrometry; PCR: polymerase chain reaction; Z9-14:OAC: (Z)-9-tetradecenyl acetate; Z7-12:OAc: (Z)-7-dodecenyl acetate; Z5-10:OAc: (Z)-5-decenyl acetate; Z9-14:OH: (Z)-9-tetradecenol; Z7-12:OH: (Z)-7-dodecenol; Z5-10:OH: (Z)-5-decenol; Z9-14:Me: (Z)-9-tetradecenoic methyl ester; Z7-12:Me: (Z)-7-dodecenoic methyl ester; Z5-10:Me: (Z)-5-decenoic methyl ester.

\section{Competing interests}

The authors declare that they have no competing interests.

\section{Authors' contributions}

BJD and CL conceived the study, BJD and CL designed the study, BJD performed the research, BJD analyzed the data, BJD and $C L$ wrote the manuscript. Both authors read and approved the final manuscript.

\section{Acknowledgements}

The study was supported by grants from Formas and VR to Christer Löfstedt and grants from the Royal Physiographic Society in Lund to Baojian Ding. We thank Åsa Hagström for advice on and assistance with the construction of gene trees, Tomas Johansson for helpful comments on the manuscript and Erling Jirle for technical support. We thank Fredrik Andersson and Erik Hedenström at Mid Sweden University for synthesizing the Z5-10:Me, Z7-12:Me and Z9-14:Me from corresponding alcohols.

Received: 28 April 2015 Accepted: 9 September 2015

Published online: 18 September 2015

\section{References}

1. Wyatt TD. Pheromones and Animal Behaviour. Communication by Smell and Taste. Cambridge: Cambridge University Press; 2003.

2. Percy-Cunningham JE, MacDonald JA. Biology and ultrastructure of sex pheromone-producing glands. In: Prestwich GD, Blomquist GJ, editors. Pheromone biochemistry. Orlando Fl: Academic; 1987. p. 27-69.

3. Ando T. 2015. (http://www.tuat.ac.jp/ antetsu/List_of_Sex_Pheromones_ in_English(2015.06.22).pdf.

4. El-Sayed AM. The Pherobase: Database of Pheromones and Semiochemicals. 2011, [http://www.pherobase.net]

5. Jurenka R. Insect pheromone biosynthesis. Topics in Curr Chem. 2004;239:97-132.

6. Blomquist GJ, Jurenka R, Schal C, Tittiger C. Biochemistry and molecular biology of pheromone production. In: Gilbet LI, Latrou K, Gill SS, editors. Comprehensive molecular insect science. London: Elsevier; 2005. p. 705-51.

7. Tillman JA, Seybold SJ, Jurenka RA, Blomquist GJ. Insect pheromones - an overview of biosynthesis and endocrine regulation. Insect Biochem Mol Biol. 1999;29:481-541.

8. Cook SM, Khan ZR, Pickett JA. The use of push-pull strategies in integrated pest management. Annu Rev Entomol. 2007;52:375-400.

9. Hagström ÅK, Wang HL, Liénard MA, Lassance JM, Johansson T, Löfstedt C. A moth pheromone brewery: production of (Z)-11-hexadecenol by heterologous co-expression of two biosynthetic genes from a noctuid moth in a yeast cell factory. Microb Cell Fact. 2013;12:125.

10. Ding BJ, Hofvander P, Wang HL, Durrett TP, Stymne S, Löfstedt C. A plant factory for moth pheromone production. Nat Commun. 2014;5:3353.

11. Wang HL, Liénard MA, Zhao CH, Wang CZ, Löfstedt C. Neofunctionalization in an ancestral insect desaturase lineage led to rare $\Delta 6$ pheromone signals in the Chinese tussah silkworm. Insect Biochem Mol Biol. 2010;40:742-51.

12. Hao GX, O'Conner M, Liu WT, Roelofs WL. Chraracterization of Z/E11- and Z9-desaturases from the obliquebanded leafroller moth, Choristoneura rosaceana. J Insect Sci. 2002;2:26.

13. Liénard MA, Strandh M, Hedenström E, Johansson T, Löfstedt C. Key biosynthetic gene subfamily recruited for pheromone production prior to the extensive radiation of Lepidoptera. BMC Evol Biol. 2008;8:270.

14. Hao G, Liu W, O'Connor M, Roelofs WL. Acyl-CoA Z9 and Z10-desaturase genes from a New Zealand leafroller moth species, Planotortrix octo. Insect Biochem Mol Biol. 2002;32:961-6. 
15. Liu WT, Jiao HM, O'Connor M, Roelofs WL. Moth desaturase characterized that produces both $Z$ and $E$ isomers of $\Delta 11$-tetradecenoic acids. Insect Biochem Mol Biol. 2002;32:1489-95.

16. Liu WT, Rooney AP, Xue BY, Roelofs WL. Desaturases from the spotted fireworm moth (Choristoneura parallela) shed light on the evolutionary origins of novel moth sex pheromone desaturases. Gene. 2004;342:303-11.

17. Moto K, Suzuki MG, Hull JJ, Kurata R, Takahashi S, Yamamoto M, et al. Involvement of a bifunctional fatty-acyl desaturase in the biosynthesis of the silkmoth, Bombyx mori, sex pheromone. Proc Natl Acad Sci U S A. 2004;101:8631-6.

18. Roelofs WL, Liu W, Hao G, Jiao H, Rooney AP, Linn Jr CE. Evolution of moth sex pheromones via ancestral genes. Proc Natl Acad Sci U S A. 2002;99(21):13621-6.

19. Ding BJ, Liénard MA, Wang HL, Zhao CH, Löfstedt C. Terminal fatty-acyl-CoA desaturase involved in sex pheromone biosynthesis in the winter moth (Operophtera brumata). Insect Bioch Mol Biol. 2011;41:715-22.

20. Moto K, Yoshiga T, Yamamoto M, Takahashi S, Okano K, Ando T, et al. Pheromone gland-specific fatty-acyl reductase of the silkmoth, Bombyx mori. Proc Natl Acad Sci U S A. 2003;100(16):9156-61.

21. Antony B, Fujii T, Moto K, Matsumoto S, Fukuzawa M, Nakano R, et al. Pheromone-gland-specific fatty-acyl reductase in the adzuki bean borer Ostrinia scapulalis (Lepidoptera: Crambidae). Insect Biochem Mol Biol. 2009:39(2):90-5.

22. Lassance JM, Groot AT, Liénard MA, Antony B, Borgwardt C, Andersson F, et al. Allelic variation in a fatty-acyl reductase gene causes divergence in moth sex pheromones. Nature. 2010;466:486-9.

23. Lassance JM, Liénard MA, Antony B, Qian S, Fujii T, Tabata J, et al. Functional consequences of sequence variation in the pheromone biosynthetic gene pgFAR for Ostrinia moths. Proc Natl Acad Sci U S A. 2013;110:3967-72.

24. Liénard MA, Hagström ÅK, Lassance JM, Löfstedt C. Evolution of multicomponent pheromone signals in small ermine moths involves a single fatty-acyl reductase gene. Proc Natl Acad Sci U S A. 2010;107:10955-60.

25. Hagström ÅK, Liénard MA, Groot AT, Hedenström E, Löfstedt C. Semi-selective fatty acyl reductases from four heliothine moths influence the specific pheromone composition. PLOS ONE. 2012;7(5):e37230.

26. Teal PEA, Tumlinson JH. Properties of cuticular oxidases used for sex pheromone biosynthesis by Heliothis zea. J Chem Ecol. 1998;14:2131-45.

27. Fang $\mathrm{N}$, Teal PEA, Tumlinson $\mathrm{JH}$. Correlation between glycerolipids and pheromone aldehydes in the sex pheromone gland of female tobacco hornworm moths, Manduca sexta (L.). Arch Insect Biochem Physiol. 1995;4:321-36.

28. Hoskovec MA, Luxová A, Svatoš A, Boland W. Biosynthesis of sex pheromones in moths: stereochemistry of fatty alcohol oxidation in Manduca sexta. Tetrahedron. 2002;58:9193-201.

29. Bestmann HJ, Herrig M, Attygalle AB. Terminal acetylation in pheromone biosynthesis by Mamestra brassicae L. (Lepidoptera:Noctuidae). Experientia. 1987:43:1033-4.

30. Teal PEA, Tumlinson JH. The role of alcohols in pheromone biosynthesis by two noctuid moths that use acetate pheromone components. Arch Insect Biochem Physiol. 1987;4:261-9.

31. Zhu JW, Zhao CH, Bengtsson M, Löfstedt C. Reductase specificity and the ratio regulation of $E / Z$ isomers in the pheromone biosynthesis of the European corn borer, Ostrinia nubilalis (Lepidoptera: Pyralidae). Insect Biochem Mol Biol. 1996;26:171-6.

32. Morse $\mathrm{D}$, Meighen E. Biosynthesis of the acetate ester precursor of the spruce budworm sex pheromone by an acetyl CoA: Fatty alcohol acetyltransferase. Insect Biochem. 1987:17:53-9.

33. Zhao CH, Lu F, Bengtsson M, Löfstedt C. Substrate specificity of acetyltransferase and reductase enzyme systems used in pheromone biosynthesis by Asian corn borer, Ostrinia furnacalis. J Chem Ecology. 1995:21:1495-510

34. Jurenka RA, Roelofs WL. Characterization of the acetyltransferase used in pheromone biosynthesis in moths: Specificity for the $\mathrm{Z}$ isomer in tortricidae. Insect Biochem. 1989;19(7):639-44.

35. Haynes KF, Hunt RE. A mutation in pheromonal communication system of cabbage looper moth, Trichoplusia ni. J Chem Ecol. 1990;16:1249-57.

36. Jurenka RA, Haynes KF, Adlof RO, Bengtsson M, Roelofs WL. Sex pheromone component ratio in the cabbage looper moth altered by a mutation affecting the fatty acid chain-shortening reactions in the pheromone biosynthetic pathway. Insect Biochem Mol Biol. 1994;24:373-81.
37. Wu WQ, Zhu JW, Millar J, Löfstedt C. A comparative study of sex pheromone biosynthesis in two strains of the turnip moth, Agrotis segetum, producing different ratios of sex pheromone components. Insect Biochem Mol Biol. 1998:28:895-900.

38. Löfstedt C, Elmfors A, Sjögren M, Wijk E. Confirmation of sex pheromone biosynthesis from $\left(16-\mathrm{D}_{3}\right)$ palmitic acid in the turnip moth using capillary gas chromatography. Experientia. 1986;42:1059-61.

39. Löfstedt C, Van Der Pers JNC, Löfqvist J, Lanne BS, Appelgren M, Bergstrom $\mathrm{G}$, et al. Sex pheromone components of the turnip moth, Agrotis segetum: chemical identification, electrophysiological evaluation and behavioral activity. J Chem Ecol. 1982;8:1305-21.

40. Löfstedt C, Löfquist J, Lanne BS, Van Der Peers JNC, Hansson BS. Pheromone dialects in European turnip moths Agrotis segetum. Oikos. 1986:46:250-7

41. Tòth M, Löfstedt C, Blair BW, Cabello T, Farag Al, Hansson BS, et al. Attraction of male turnip moths Agrotis segetum (lepidoptera, noctuidae) to sex-pheromone components and their mixtures at 11 sites in Europe, Asia, and Africa. J Chem Ecol. 1992;18(8):1337-47.

42. Strandh M, Johansson T, Ahren D, Löfstedt C. Transcriptional analysis of the pheromone gland of the turnip moth, Agrotis segetum (Noctuidae), reveals candidate genes involved in pheromone production. Insect Mol Biol. 2008; 17(1):73-85.

43. Miller JR, Koren S, Sutton G. Assembly algorithms for next-generation sequencing data. Genomics. 2010;95:315-27.

44. Conesa A, Götz S, García-Gómez JM, Terol J, Talón M, Robles M. Blast2GO: a universal tool for annotation, visualization and analysis in functional genomics research. Bioinformatics. 2005;21(18):3674-6.

45. Gu SH, Wu KM, Guo YY, Pickett JA, Field LM, Zhou JJ, et al. Identification of genes expressed in the sex pheromone gland of the black cutworm Agrotis ipsilon with putative roles in sex pheromone biosynthesis and transport. BMC Genomics. 2013;14:636.

46. Zhu J, Millar J, Löfstedt C. Hormonal regulation of sex pheromone biosynthesis in the turnip moth, Agrotis segetum. Archs Insect Biochem Physiol. 1995;30:41-59.

47. Choi MY, Fuerst EJ, Rafaeli A, Jurenka R. Identification of a $G$ protein-coupled receptor for pheromone biosynthesis activating neuropeptide from pheromone glands of the moth Helicoverpa zea. Proc Natl Acad Sci U S A. 2003;100:9721-6.

48. Matsumoto S, Ozawa R, Nagamine T, Kim GH, Uchiumi K, Shono T, et al. Intracellular transduction in the regulation of pheromone biosynthesis of the silkworm, Bombyx mori: suggested involvement of calmodulin and phosphoprotein phosphatase. Biosci Biotechnol Biochem. 1995:59:560-2.

49. Jurenka RA, Jacquin E, Roelofs WL. Stimulation of pheromone biosynthesis in the moth Helicoverpa zea: Action of a brain hormone on pheromone glands involves $\mathrm{Ca}^{2+}$ and CAMP as second messengers. Proc Natl Acad Sci U S A. 1991;88:8621-5.

50. Mas E, Llòria J, Quero C, Camps F, Fabriàs G. Control of the biosynthetic pathway of Sesamia nonagrioides sex pheromone by the pheromone biosynthesis activating neuropeptide. Insect Biochem Mol Biol. 2000;30:455-9.

51. Pape ME, Lopezcasillas F, Kim KH. Physiological regulation of acetyl-CoA carboxylase gene expression: effects of diet, diabetes, and lactation on acetyl-CoA carboxylase mRNA. Arch Biochem Biophys. 1988;267(1):104-9.

52. Volpe JJ, Vagelos PR. Saturated fatty acid biosynthesis and its regulation. Annu Rev Biochem. 1973;42:21-60.

53. Tang JD, Charlton RE, Jurenka RA, Wolf WA, Phelan PL, Sreng L, et al. Regulation of Pheromone Biosynthesis by a Brain Hormone in 2 Moth Species. Proc Natl Acad Sci U S A. 1989;86(6):1806-10.

54. Bjostad LB, Roelofs WL. Biosynthesis of sex pheromone components and glycerolipid precursors from sodium [1-14C] acetate in redbanded leafroller moth. J Chem Ecol. 1984;10:681-91.

55. Hashimoto K, Yoshizawa AC, Okuda S, Kuma K, Goto S, Kanehisa M. The repertoire of desaturases and elongases reveals fatty acid variations in 56 eukaryotic genomes. J Lipid Res. 2008:49:183-91.

56. Knipple DC, Rosenfield CL, Nielsen R, You KM, Jeong SE. Evolution of the integral membrane desaturase gene family in moths and flies. Genetics. 2002;162(4):1737-52.

57. Jeong SE, Rosenfield CL, Marsella-Herrick P, Man You K, Knipple DC. Multiple acyl-CoA desaturase-encoding transcripts in pheromone glands of Helicoverpa assulta, the oriental tobacco budworm. Insect Biochem Mol Biol. 2003;33:609-22. 
58. Vogel H, Heidel AJ, Heckel DG, Groot AT. Transcriptome analysis of the sex pheromone gland of the noctuid moth Heliothis virescens. BMC Genomics. 2010;11:29.

59. Ikeda Y, Okamura-Ikeda K, Tanaka K. Purification and characterization of short-chain, medium-chain, and long-chain acyl-CoA dehydrogenases from rat liver mitochondria. Isolation of the holo- and apoenzymes and conversion of the apoenzyme to the holoenzyme. J Biol Chem. 1985;260:1311-25

60. Izai K, Uchida Y, Orii T, Yamamoto S, Hashimoto T. Novel fatty acid beta-oxidation enzymes in rat liver mitochondria. I. Purification and properties of very-long-chain acyl-coenzyme A dehydrogenase. J Biol Chem. 1992;267:1027-33.

61. Schulz H. Oxidation of fatty acids in eukaryotes. In: Vance DE, Vance J, editors. Biochemistry of Lipids, Lipoproteins and Membranes. 5th ed. Amsterdam: Elsevier; 2008. p. 131-54.

62. Kunau $\mathrm{WH}$, Dommes $\mathrm{V}$, Schulz $\mathrm{H}$. beta-oxidation of fatty acids in mitochondria, peroxisomes, and bacteria: a century of continued progress. Prog Lipid Res. 1995:34:267-342.

63. Uchida Y, Izai K, Orii T, Hashimoto T. Novel fatty acid beta-oxidation enzymes in rat liver mitochondria. II. Purification and properties of enoyl-coenzyme A (CoA) hydratase/3-hydroxyacyl-CoA dehydrogenase/3-ketoacyl-CoA thiolase trifunctional protein. J Biol Chem. 1992;267:1034-41.

64. Schreurs M, Kuipers F, van der Leij FR. Regulatory enzymes of mitochondrial beta-oxidation as targets for treatment of the metabolic syndrome. Obes Rev 2010;11:380-8.

65. Stanley-Samuelson DW, Jurenka RA, Cripps C, Blomquist GJ, de Renobales M. Fatty acids in insects: composition, metabolism, and biological significance. Arch Insect Biochem Physiol. 1988;9:1-33.

66. Hashimoto T. Peroxisomal $\beta$-oxidation: enzymology and molecular biology. Ann N Y Acad Sci. 1996;804:86-98.

67. Liénard MA, Löfstedt C. Functional flexibility as a prelude to signal diversity?: role of a fatty acyl reductase in moth pheromone evolution. Commun Integr Biol. 2010;3(6):586-8.

68. Itoh N, Slemmon J, Hawke D. Cloning of Drosophila choline acetyltransferase cDNA. Proc Natl Acad Sci U S A. 1986;83:4081-5.

69. Günther CS, Chervin C, Marsh KB, Newcomb RD, Souleyre EJ. Characterisation of two alcohol acyltransferases from kiwifruit (Actinidia spp.) reveals distinct substrate preferences. Phytochem. 2011;72:700-10.

70. Beekwilder J, Alvarez-Huerta M, Neef E, Verstappen FWA, Bouwmeester HJ, Aharoni A. Functional characterization of enzymes forming volatile esters from strawberry and banana. Plant Physiol. 2004;135:1865-78.

71. Kalscheuer R, Stoveken T, Luftmann H, Malkus U, Reichelt R, Steinbüchel A. Neutral lipid biosynthesis in engineered Escherichia coli: jojoba oil-like wax esters and fatty acid butyl esters. Appl Environ Microbiol. 2006;72:1373-9.

72. Uthoff S, Stoveken T, Weber N, Vosmann K, Klein E, Kalscheuer R, et al. Thio wax ester biosynthesis utilizing the unspecific bifunctional wax ester synthase/acyl coenzyme A: diacylglycerol acyltransferase of Acinetobacter sp. strain ADP1. Appl Environ Microbiol. 2005;71:790-6.

73. St-Pierre B, De Luca V. Evolution of acyltransferase genes: origin and diversification of the BAHD superfamily of acyltransferases involved in secondary metabolism. In: Ibrahim R, Varin L, De Luca V, Romeo JT, editors. Recent Advances in Phytochemistry Evolution of Metabolic Pathways. 2000, 34: 285-315

74. D'Auria J. Acyltransferases in plants: a good time to be BAHD. Curr Opin Plant Biol. 2006:9:331-40

75. Fujii T, Ito K, Katsuma S, Nakano R, Shimada T, Ishikawa Y. Molecular and functional characterization of an acetyl-CoA acetyltransferase from the adzuki bean borer moth Ostrinia scapulalis (Lepidoptera: Crambidae). Insect Biochem Mol Biol. 2009;40:74-8.

76. Souleyre EJF, Greenwood DR, Friel EN, Karunairetnam S, Newcomb RD. An alcohol acyl transferase from apple (cv. Royal Gala), MpAAT1, produces esters involved in apple fruit flavor. FEBS J. 2005;272:3132-44.

77. Yahyaoui FE, Wongs-Aree C, Latche A, Hackett R, Grierson D, Pech JC. Molecular and biochemical characteristics of a gene encoding an alcohol acyl-transferase involved in the generation of aroma volatile esters during melon ripening. Eur J Biochem. 2002;269:2359-66.

78. Aharoni A, Keizer LC, Bouwmeester HJ, Sun Z, Alvarez-Huerta M, Verhoeven $H A$, et al. Identification of the SAAT gene involved in strawberry flavor biogenesis by use of DNA microarrays. Plant Cell. 2000;12:647-62.

79. Zhu JW, Löfstedt C, Bengtsson BO. Genetic variation in the strongly canalized sex pheromone communication system of the European corn borer Ostrinia nubilalis Hübner (Lepidoptera; Pyralidae). Genetics. 1996;144:757-66.
80. Ma PWK, Ramaswamy SB. Biology and ultrastructure of sex pheromoneproducing tissue. In: Blomquist GJ, Vogt RG, editors. Insect pheromone biochemistry and molecular biology. London: Elsevier; 2003. p. 19-51.

81. Rosén W. Endogenous control of circadian rhythms of pheromone production in the turnip moth, Agrotis segetum. Arch Insect Biochem Physiol. 2002;50:21-30.

82. Grabherr MG, Haas BJ, Yassour M, Levin JZ, Thompson DA, Amit I, et al. Full-length transcriptome assembly from RNA-Seq data without a reference genome. Nat Biotechnol. 2011;29:644-52.

83. Pertea G, Huang X, Liang F, Antonescu V, Sultana R, Karamycheva S, et al. TIGR Gene Indices clustering tools (TGICL): a software system for fast clustering of large EST datasets. Bioinformatics. 2003;19:651-2.

84. Mortazavi A, Williams BA, McCue K, Schaeffer L, Wold B. Mapping and quantifying mammalian transcriptomes by RNA-Seq. Nat Methods. 2008;5:621-8.

85. Trapnell C, Williams BA, Pertea G, Mortazavi A, Kwan G, van Baren MJ, et al. Transcript assembly and quantification by RNA-Seq reveals unannotated transcripts and isoform switching during cell differentiation. Nat Biotechnol. 2010;28:511-5.

86. Tatusov RL, Koonin EV, Lipman DJ. A genomic perspective on protein families. Science. 1997;278:631-7.

87. Ye J, Fang L, Zheng H, Zhang Y, Chen J, Zhang Z, et al. WEGO: a web tool for plotting GO annotations. Nucleic Acids Res. 2006:34:W293-297.

88. Tamura K, Dudley J, Nei M, Kumar S. MEGA4: Molecular evolutionary genetics analysis (MEGA) software version 4.0. Mol Biol Evol. 2007;24:1596-9.

89. Bjostad BL, Roelofs LW. Sex pheromone biosynthetic precursors in Bombyx mori. Insect Biochem. 1984;14:275-8.

\section{Submit your next manuscript to BioMed Central and take full advantage of:}

- Convenient online submission

- Thorough peer review

- No space constraints or color figure charges

- Immediate publication on acceptance

- Inclusion in PubMed, CAS, Scopus and Google Scholar

- Research which is freely available for redistribution 